\title{
Clergy Attitudes Toward Credit/Debt
}

\author{
Kristina Terkun \\ Our Lady of the Lake University
}

Peñaloza and Barnhart (2011) identify patterns of meanings in credit/debt based on U.S. white middle class informants' interactions in the social and market domains. These patterns may yield "efficacious" or "punished" consumption outcomes, among which informants often move due to life events. This study draws upon $P \& B$ 's framework, using depth interviews to gather insight into meanings in credit/debt for clergy; specifically, ordained Baptists, Catholics, and Lutherans of varying racial/ethnic backgrounds in the U.S. Participants are found to hold various types of personal debt and face influences similar to nonclergy, leading to the normalization of credit/debt and impacting their consumption outcomes.

Keywords: credit, debt, clergy, pastors, financial literacy

\section{INTRODUCTION}

Clergy indebtedness is problematic both personally and professionally, as well as for the congregation or parish. Pastors burdened by personal debt (e.g., mortgage, car loan, student loan, credit card) can empathize with parishioners who find themselves in similar circumstances, but may not be in a position to advise on such matters. In fact, clergy may be worse off having to manage higher debt to salary ratios, since expected lifetime earnings are relatively low based on educational attainment (see Table 1). Moreover, ministering to others could prove challenging for clergy when concerned about their own finances. Understanding clergy attitudes toward credit/debt, and how they handle credit/debt, is an essential first step in addressing clergy financial literacy and to helping them to become more effective leaders. The purpose of this investigation is to identify clergy attitudes toward credit/debt and to determine what patterns may exist among clergy as consumers. 
(Millions 2009 dollars)

$\begin{array}{lclr} & \text { All workers } & & \text { Clergy } \\ \text { Some college/no degree } & 1.5 & & 1.4 \\ \text { Bachelor's degree } & 2.3 & \text { Master's/Professional/ } & 1.6 \\ & & \text { Doctoral } & 1.8 \\ \text { Master's degree } & 2.7 & & \\ \text { Doctoral degree } & 3.3 & & \\ \text { Professional degree } & 3.6 & \end{array}$

NOTE-Approximately 77 percent of clergy hold BA and/or graduate degrees.

Source: An analysis of the 2007-2009 American Community Survey (U.S. Census Bureau), from Carnevale, Cheah, Rose, and Georgetown University (2011).

Worth mentioning is that since this study was completed, the coronavirus (COVID-19) pandemic of 2020 has affected the world in ways entirely unforeseen, including the livelihood of clergy. Further details of some of the events as they have played out, and their impact on clergy, may be found in Appendix A.

Consequently, the remainder of this article is organized as follows. The next section provides a review of the existing literature. The two sections that follow introduce the methods used and data collected, after which there is an analysis of informants' practices and experiences with credit/debt and a discussion shedding light on patterns among clergy informants. In the final section are the concluding remarks and proposed areas for further research.

\section{LITERATURE REVIEW}

\section{Clergy Finances}

To date, scholarly research is lacking on clergy as consumers, how they handle their personal finances, and their interactions with credit/debt in particular. Some articles have touched on the role of ministers in church finances (DeLambo, 2005; Zech and Miller, 2005). In addition, there exist a plethora of studies commissioned by religious associations and centers regularly reported in news articles that reveal the overwhelming levels of personal debt facing clergy. However, these press releases tend to focus on the stress that this creates for clergy.

Other studies have tackled a variety of subjective topics in relation to clergy. Rhee, Chang, and Youn (2003) analyze pastors' attitudes toward child abuse, and Long and Heggen (1988) explore clergy perceptions of spiritual health. An investigation of clergy attitudes toward credit/debt would extend this body of work and could shed light on how best to advise clergy on issues surrounding personal debt.

\section{On Credit and Debt: The Peñaloza-Barnhart Model}

The inspiration for this study comes from the literature on consumer research, specifically Peñaloza and Barnhart's [P\&B] (2011) article on the normalization of credit/debt. Using depth interviews and qualitative analysis, $P \& B$ examine attitudes toward credit/debt in the U.S. for the white middle class. They identify patterns based on how individuals interact with credit/debt, as well as the trajectories that can lead them to better ("efficacious") or worse ("punished") positions as consumers. Knowledge of these patterns suggests that it may be possible to alter one's trajectory given a different "meaning pattern" or set of attitudes. A review of the P\&B model and relationships expressed therein follows (as depicted in Figure 1). 


\section{Meaning Patterns}

P\&B's cultural meanings are derived from informants' interactions with credit/debt in the social and market domains, that is, with friends and family, and financial institutions, respectively. P\&B identify three patterns of meanings across these domains. At one end of the spectrum is "Doing the Right Thing" (DRT), consistent with the attributes a financial advisor might recommend. This includes using credit/debt to exert one's independence (e.g., to purchase a home or for educational expenses, without depending on others); exercising self-discipline by delaying gratification and limiting the use of credit/debt in relation to one's available resources; generally viewing credit/debt in a negative light, that is, as a threat; and attaining freedom to access additional credit in the marketplace due to timely repayment of debt, as well as receiving low rates, awards, and a desirable credit score. At the other extreme, is the pattern of "Managing Debt." In this case, one is using credit/debt for social integration, or to live up to others' material expectations (e.g., to purchase new furniture or spend money on an extravagant wedding); is engaging in indulgence by pursuing one's own desires beyond available resources; has an optimistic view of credit/debt, that is, as security in emergencies; and finds oneself in a constraint situation, subject to higher fees and a bad credit score, perhaps due to late/insufficient payments on debt. The "Hybrid" pattern lies between the preceding patterns and consists of various combinations of meanings lying somewhere between the two.

\section{FIGURE 1}

\section{PEÑALOZA AND BARNHART FRAMEWORK}

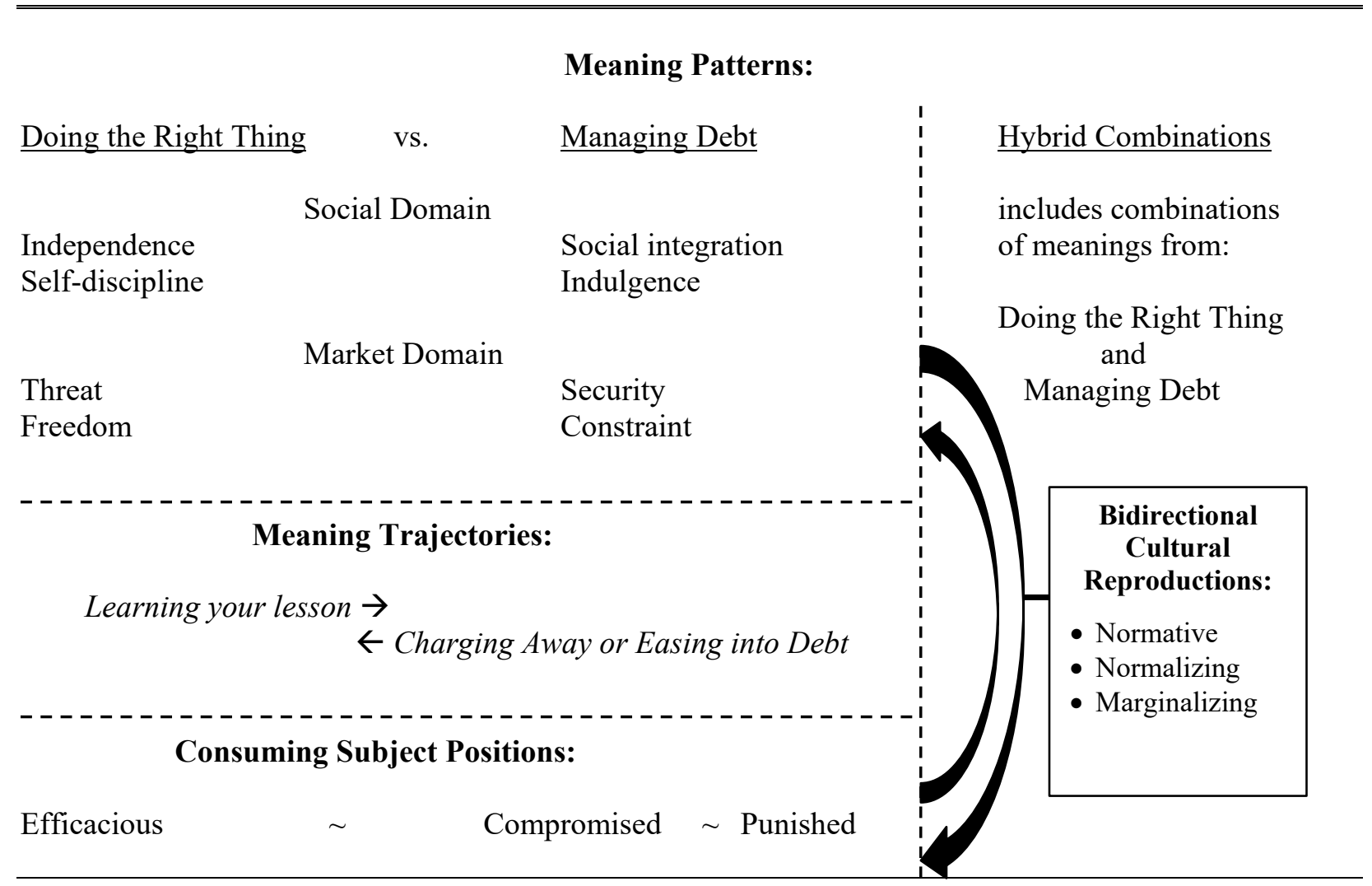

Source: Peñaloza and Barnhart (2011)

\section{Meaning Trajectories}

Although P\&B found the aforementioned meaning patterns to be relatively stable, it is possible for informants to move between them over time. For instance, one might be DRT but find oneself quickly "charging away" or just gradually "easing into debt," resulting in Managing Debt. These movements often 
are triggered by life events, for example, graduation, starting a career, marriage/divorce, having children, and unexpected health issues. "Learning your lesson" is also possible and can lead once again to DRT.

\section{Consuming Subject Positions}

All three meaning patterns impact informants' positions as consumers, yielding outcomes that are "efficacious," "compromised," or "punished." Informants who are DRT tend to present an efficacious position. $\mathrm{P} \& \mathrm{~B}$ attribute "self-discipline and viewing credit as a threat, [as] vital in constituting the efficacious consuming subject" position (2011, p.759). The trajectory, learning your lesson, can also lead to this outcome. Informants exhibiting a Hybrid Combination are likely to be categorized as efficacious or compromised. "Higher fees, compound interest charges, poor credit ratings, and limited additional credit" characterize the compromised position (P\&B, 2011, p.757). Finally, those who are Managing Debt might find themselves compromised or, in the extreme, punished. Following the trajectories charging away or easing into debt can result in a compromised position. Punished consumers might also be subject to "harassing letters and calls from collection agencies, product repossession [...], and attempted home foreclosure" (P\&B, 2011, p.757).

\section{Cultural Reproductions}

The connection between meaning patterns and consuming subject positions depends on one's "bidirectional cultural reproduction," that is, whether the informant is expressing a "normative," "normalizing," or "marginalizing" consumption ethic. Normative cultural production includes what informants believe they and/or others should do. P\&B observe that normalizing, or what one normally does, often is achieved through "improvising meaning combinations" (2011, p.756). Lastly, marginalizing cultural production is defined more so based on what informants consider "abnormal in establishing what is normal in credit/debt" (P\&B, 2011, p.757). While informants DRT often demonstrated a normative consumption ethic in the $\mathrm{P} \& \mathrm{~B}$ study, some degree of normalization of credit/debt could be found across all meaning patterns and encompassed fully the Hybrid Combinations. Marginalization was exclusive to Managing Debt and a punished consuming subject position.

In sum, the following questions in this study rely on the framework established by P\&B. To what extent do clergy attitudes toward credit/debt reflect the meaning patterns and corresponding consuming subject positions derived by $\mathrm{P} \& \mathrm{~B}$ ? Are particular patterns prevalent among clergy? Finally, what may be the similarities or differences across clergy of different denominations?

\section{METHODS}

This study uses methods similar to those employed by P\&B. Their "research design combines oral history with depth interviews in examining credit/debt discourses and practices over the lives of informants. Data were collected in a major city in the Midwestern United States in 2005 and 2006" (2011, p.745). Further, P\&B "recruited [...] informants by distributing flyers and snowballing personal contacts" (2011, p.745). Ultimately, 27 white middle-class informants were interviewed. Interviews consisted of questions on credit/debit histories, practices, and perspectives on culture and debt and "lasted 45-90 minutes" (2011, p.747). Finally, $P \& B$ analyzed the discourses searching for various meanings and subsequent patterns (or themes) across informants, which they linked to particular consuming subject positions.

For the purpose of this study, depth interviews were conducted using questions directly obtained from P\&B. Interviews were audio-recorded and transcribed. Informants' responses were then coded and analyzed. Content analysis was used to identify particular meanings and to tease out clergy attitudes toward credit/debt.

In contrast with the P\&B study, informants were selected from among clergy; specifically, Baptist, Lutheran, and Catholic pastors in a major urban area in the South Central United States. Prospective participants were solicited via (postal) mail from readily available sources, including an archdiocese listing of parishes, as well as a general Baptist association and Lutheran directories of churches in the area. In all, this came to 359 letters posted. More than half of those solicited were Baptists, followed most closely by 
Catholics and then Lutherans, in line with the respective rankings of congregations in the area. Initially, only 11 clergy responded to the solicitations, while five more Catholic clergy were contacted via snowballing. Consequently, a final group of 16 participants was secured for interviews.

Data from the Association of Statisticians of American Religious Bodies (ASARB) indicates that the SBC, Roman Catholic Church (RCC), and the Evangelical Lutheran Church in America (ELCA) have the greatest number of congregations among Baptists, Catholics, and Lutherans, respectively, at all geographic levels represented (2010). The informants in this study break down similarly. They consist of seven Baptist (B) pastors, affiliated foremost with the Southern Baptist Convention (SBC), followed by the Cooperative Baptist Fellowship (CBF), and the National Baptist Convention of America (NBCA); six Roman Catholic clergy, including four diocesan (DI) and two religious order (RO) priests; and three Lutheran (L) pastors from the ELCA. All clergy included in this study are ordained. Figure 2 shows the distribution of clergy informants in this study versus that of congregations by "family type" in the U.S., as well as in the focus state and county herein.

Of marked interest in this study is whether P\&B's model offers insight into clergy attitudes toward credit/debt. Although P\&B patterns are based on the white middle class in the U.S., the overall demographic makeup of their informants is arguably still amenable to framing clergy as "consuming subjects." Following is a comparison of $\mathrm{P} \& \mathrm{~B}$ informant characteristics with those of the clergy informants.

FIGURE 2

\section{RELATIVE DISTRIBUTION OF CONGREGATIONS VERSUS CLERGY INFORMANTS}

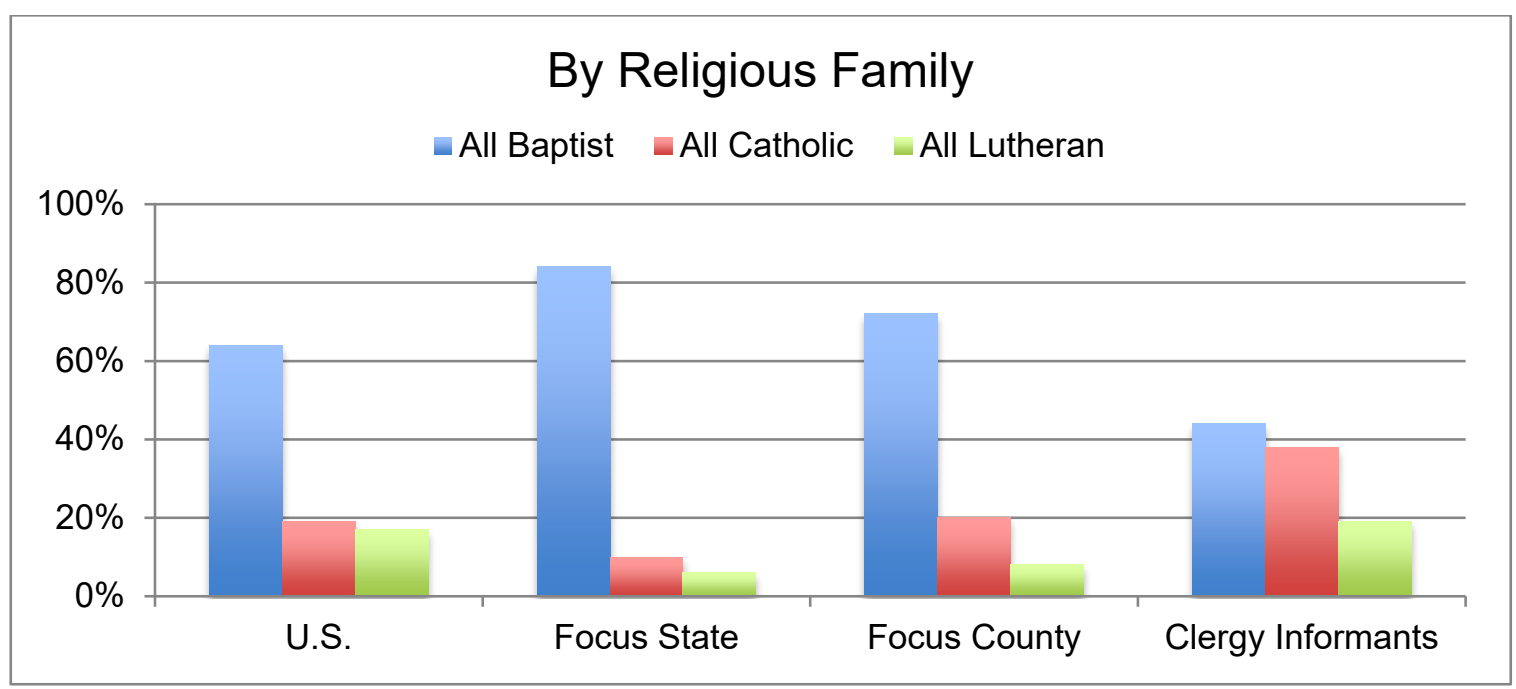

Source: Association of Statisticians of American Religious Bodies (2010)

Age: According to a study conducted with Pepperdine University, the typical age of a pastor in the U.S. is 44 , and 68 percent of pastors are between the ages of 40 and 65 (Barna Group, 2017). More than one third of $\mathrm{P} \& \mathrm{~B}$ informants also fall within this age range. The majority of clergy informants are above 50 years of age.

Marital status and children: In addition, over half of P\&B informants are married (another third are single, and the remainder are divorced) and nearly half have at least one child. Similarly, the majority of clergy herein are married and with children.

Education and income: Almost half of P\&B informants earned college degrees, and 80 percent of those degrees were terminal at the bachelor's or master's levels. Incomes reported by employed informants-half of which are household incomes - ranged from $\$ 19,200$ to $\$ 269,000$, and the median income is $\$ 44,00$, in contrast with a $M=\$ 81,110$. Ordained clergy generally are required to have college degrees and this is true of the informants in this study. Moreover, all but two clergy have at least a master's degree. In addition, 
clergy household incomes range from $\$ 19,000$ to $\$ 250,000$. The median clergy household income is $\$ 80,000$, versus a $M=\$ 89,375$.

Aside from focusing on clergy, there are some key differences between these informants and those in the P\&B study. Specifically, in the areas of:

Race/ethnicity: $\mathrm{P} \& \mathrm{~B}$ informants were all selected from among the white middle class. According to $\mathrm{P} \& \mathrm{~B}$, this was done "due to their position at the center of U.S. society" and because they were looking to offer "insight into U.S. culture and institutions more generally" (P\&B, 2011, p.745). In contrast, clergy informants come from different racial/ethnic backgrounds. Slightly more than half are Hispanic or black, followed by those who are white. All Lutheran participants are white. Baptist participants include all blacks in the study, followed by Hispanics and whites. Diocesan and religious Catholics are both evenly split among Hispanics and whites.

Gender: Just under half of P\&B informants are female, whereas all clergy informants are male.

Summary characteristics for clergy informants are presented in Table 2. A more detailed table, including income and debt information, may be found in Appendix B.

TABLE 2

SUMMARY CHARACTERISTICS OF INFORMANTS $(\mathbf{N}=16)$

\begin{tabular}{|c|c|c|c|}
\hline \multicolumn{2}{|l|}{ Religious affiliation } & \multicolumn{2}{|c|}{ Education (highest degree earned) } \\
\hline Protestant & 10 & Bachelor's & 2 \\
\hline \multirow[b]{3}{*}{ Catholic } & 7 & Master's & 13 \\
\hline & 3 & Doctorate & 1 \\
\hline & 6 & \multicolumn{2}{|l|}{ Gender } \\
\hline Diocesan & 4 & Male & 16 \\
\hline Religious Order & 2 & Female & 0 \\
\hline \multicolumn{2}{|l|}{ Race/Ethnicity } & \multicolumn{2}{|l|}{ Status } \\
\hline Black & 4 & Married & $10^{*}$ \\
\hline Hispanic & 5 & Single & $6^{* *}$ \\
\hline White & 7 & & \\
\hline \multicolumn{2}{|c|}{ Age $($ range $=37-71), M=58$} & \multicolumn{2}{|c|}{ Children \# (1-4), ages (16-51) } \\
\hline $25-39$ & 1 & Yes & $10^{*}$ \\
\hline $40-49$ & 2 & No & $6^{* *}$ \\
\hline $50-59$ & 6 & & \\
\hline $60-69$ & 6 & & \\
\hline $70+$ & 1 & & \\
\hline
\end{tabular}

\section{DATA}

The following data come from interviews with Baptist (B) and Lutheran (L) pastors, as well as Catholic diocesan (DI) and religious order (RO) priests. Pseudonyms are used to identify individual informants along 
with abbreviations to highlight their respective "denominations." To establish informants' backgrounds, first there is an exploration of their histories with credit/debt, including their initial exposure, and how they define credit/debt. A breakdown of their current debt by loan type follows, as well as how their debts compare with income, and whether there is any relation to age, race or ethnicity, and family structure. Due to the small sample of clergy, any patterns that arise within this group of informants may not be generalizable to the larger population of clergy.

\section{Credit and Debt}

Initial Exposure

The vast majority of informants initially used credit in their teenage years, as young as age fifteen and into their early 20s. Common, memorable, first purchases across denominations included auto-related expenditures (e.g., a first car, a repair and a car battery purchase) and opening a credit card with a gasoline company. Jake (L) opened a few of these cards, since "everyone" advised him that doing so was a good way to establish credit. Only two informants said that they had "never used credit." This literally was the case for Henry (RO, age 44), who joined a religious order immediately after high school and had not ever used credit or been in debt. However, Andrew (DI, age 40) seemed to consider only credit cards to be credit, since he did at one time have a student loan and currently has a car loan. Nick (B) is originally from Central America and did not use credit/debt until obtaining a mortgage at age 40, having only arrived in the U.S. in his early thirties.

\section{Definitions}

Clergy were asked to define credit and debt. A handful of informants took a practical or utilitarian approach to their definitions of credit, by focusing principally on what Albert (B) referred to as a "contract" or "understanding" to borrow money with the expectation or promise of that money being repaid with interest in the future.

Across clergy, feelings on whether credit is good or bad were somewhat mixed. On a positive note, Henry (RO) - who never used credit_-identified it as "something you build upon" to ensure a greater standard of living. Several more Baptist informants alluded to credit as fulfilling something that is needed and/or lacking, and therefore acquired elsewhere, but shared some conflicting feelings on its power to subjugate. According to David (B), it is "enslavement... to whatever you've got credit for" but also "something that will improve your life," and for Nick (B), "there is nothing wrong with them [credit/debt], as long as you know how to manage and you don't become slave to it." Andrew (DI) also acknowledged that credit is used for things that cannot be paid for "up front." Nonetheless, he viewed credit as a "bad thing," noting that "if you don't have money to, why go get something." Others like Eric (B) and Mike (DI), associated credit with "responsibility" and "power," respectively.

Debt was defined most simply by Jake (L) as an "excess of liabilities over assets;" a perspective reflected by informants across denominations. However, informants in general were more cautious and expressed more negative feelings about debt than was the case with credit. Steve's (B) impression of debt was that "too much of it is bad." Henry (RO) classified debt as "negative" and noted how it can create a constraining situation by leading to bankruptcy. Consequently, both Bruce (DI) and Nick (B) underscored the importance of having a "plan." Perhaps the most striking of the unfavorable comments came from Baptists David and Scott. David characterized debt as an "enemy" and attributed debt other than a house or car to "when you're out of control." Likewise, Scott pondered whether debt in general might be the "result of greater personal issues," as compensation for not liking who you are.

\section{Similarities Versus Differences}

Credit and debt were commonly regarded as "similar" or "synonymous," according to diocesan priests, Bruce and Mike. In certain cases, both were deemed "necessities" since, as Steve (B) put it, you "can't even rent a car without a credit card." George (B) consequently, resigned himself to the notion that "they're [credit and debt] gonna always be there." Here, Sam (RO) calls attention to the causal relationship between credit and debt: 
Well, sometimes it's necessary to use credit, for something that you absolutely have to have that you might not have the money for. Which means you're going into debt. Any time. I mean, I would consider the use of credit as creating debt, because you owe it. It's not like, just because you've got credit it's yours and you don't have to pay it back. So it is a debt that you owe.

Lutherans Jake and John differentiated between credit and debt, either in terms of having a plan or having certain resources available. Jake (L) described credit as buying something, knowing that at a definite point you are going to have money to pay for it, for example due to a bonus, selling a house, or having additional cash, in contrast with debt as a failure to have a definite payoff plan. John (L) viewed credit as immediately available without using an institution and debt as borrowed from someone else (who has credit). On the other hand, Bob (DI) interpreted credit as something on which one was to be evaluated, whereas debt was something one had already incurred.

\section{Mortgages and Student Loans}

Few informants referred to a mortgage or house payment purely as debt, with the exception of Baptists Eric, Albert, and Nick. More readily, a mortgage was either an "investment" (David, B; Bob, DI; Daniel, L) or "good debt" (Scott, B), along with student loans (Andrew, DI). Jake (L) was the only informant to go so far as to say that a mortgage is "credit, cause I could pay the thing off."

\section{Current Debt}

Informants' current debt loads (at the time of their interview) are evaluated according to types of debt held, with the exception of Catholic priests Henry and Sam. They are members of a religious order and, as Henry explained, it is "forbidden to be in debt." Worth noting is that religious order priests take a vow of poverty, and diocesan priests do not. Consequently, diocesan priests may own property (e.g., a house or car, etc.), or might instead live in parish-owned housing. Henry had no experience with credit/debt. However, Sam did use credit cards that he consistently paid off in full each month.

As shown in Figure 3, within each denomination (Baptist, Lutheran, Catholic-DI), there are clergy with mortgages, auto loans, and credit card (or other types of) debt. Only one informant (Scott, B) reports having a school loan, belonging to his wife. Among Baptists and Lutherans, a mortgage is the most common type of debt, followed by auto loans, and credit card (or other) debt. In contrast, more diocesan priests have auto loans than credit card debt and only Bob has a mortgage. The remaining (diocesan) priests reside in parishowned housing.

Baptist and Lutheran clergy are also grouped as Protestants versus Catholics (including only diocesan priests) to compare the distribution of debt according to debt type (see Figure 4a). The distribution of debt (in descending order) for Protestants and Catholics matches that of the state in which the interviews were conducted, with mortgage debt far exceeding all other types, followed by auto loans and credit card (or other) debt. However, Protestant debt in the form of student loans is less than for the focus state. Further, the clergy informant group consists of individuals ages 37-71, whereas the comparative survey data includes adults, age 19 and older (as well as women). Although the proportion of total debt among Catholics is higher in the mortgage category than for Protestants, this reflects a mortgage held by only one priest (Bob). 
FIGURE 3

CLERGY COUNTS BY DEBT TYPE AND DENOMINATION

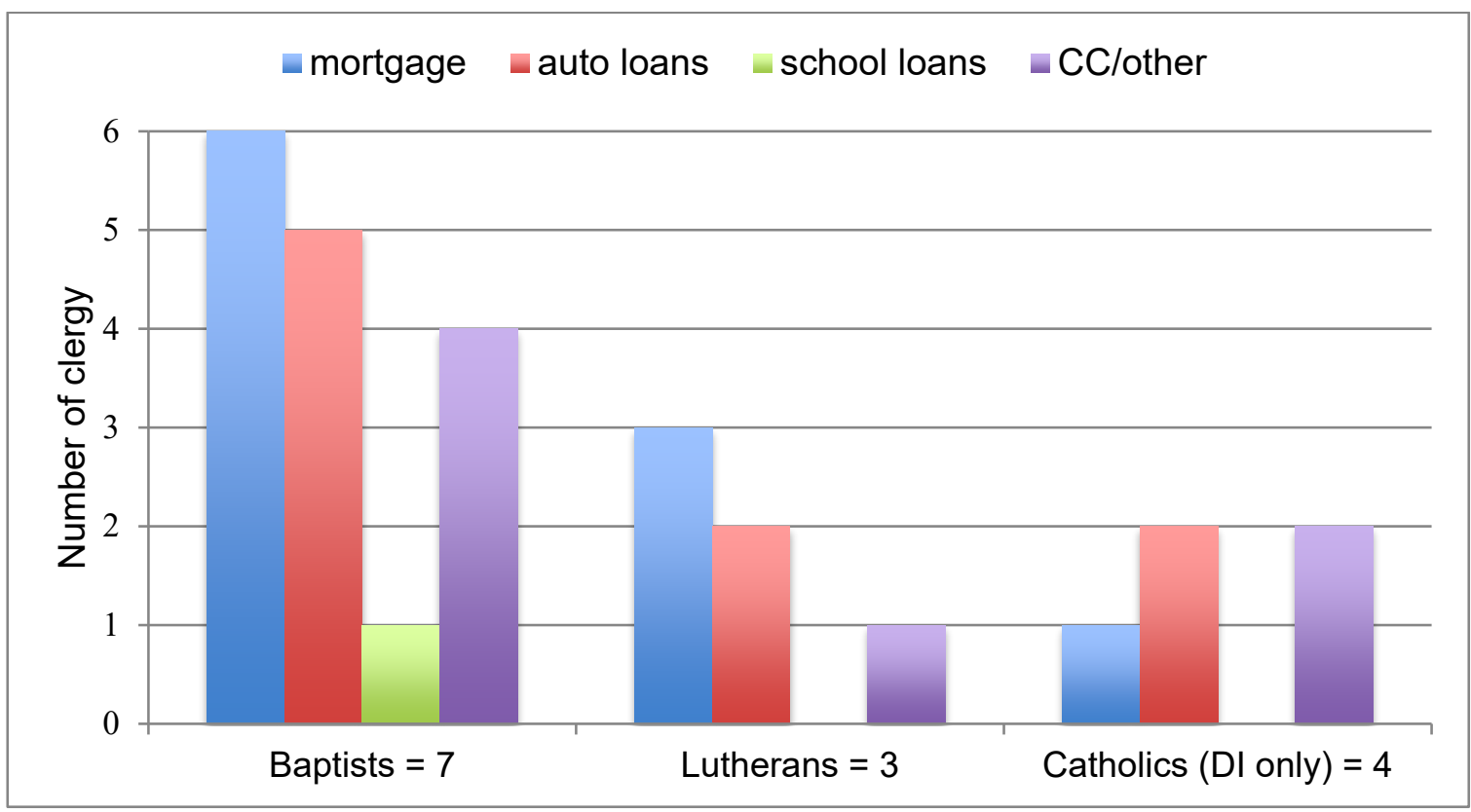

Figure $4 \mathrm{~b}$ shows the distribution of debt across different types of debt by denomination. Among Protestants, Lutherans have the greatest percentage devoted to mortgage debt. Given that Lutherans have no student loans, they more closely approximate Catholics than Baptists, but only slightly.

FIGURE 4

\section{A. DISTRIBUTION OF TOTAL DEBT BY TYPE}

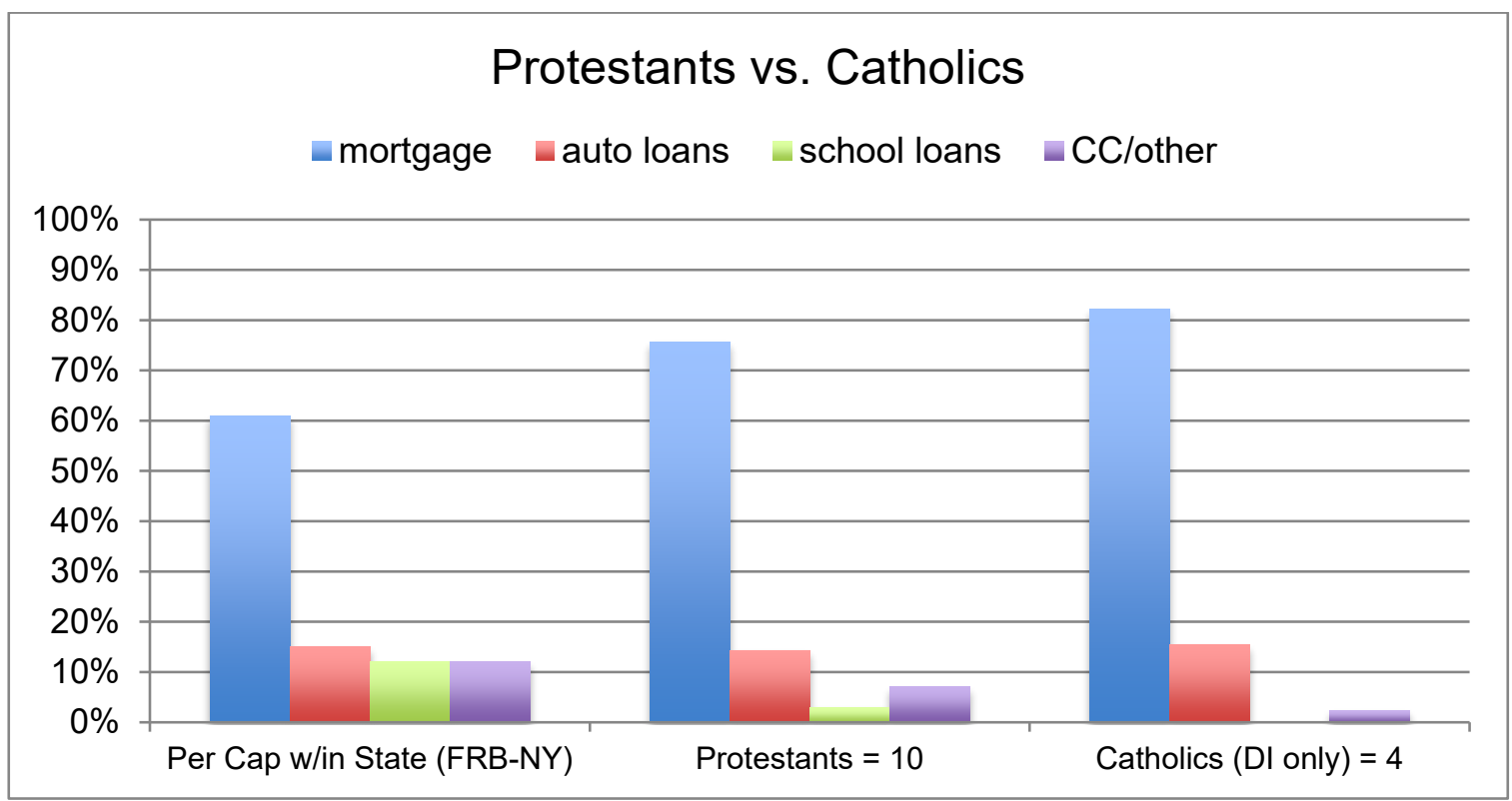




\section{B. DISTRIBUTION OF TOTAL DEBT BY TYPE}

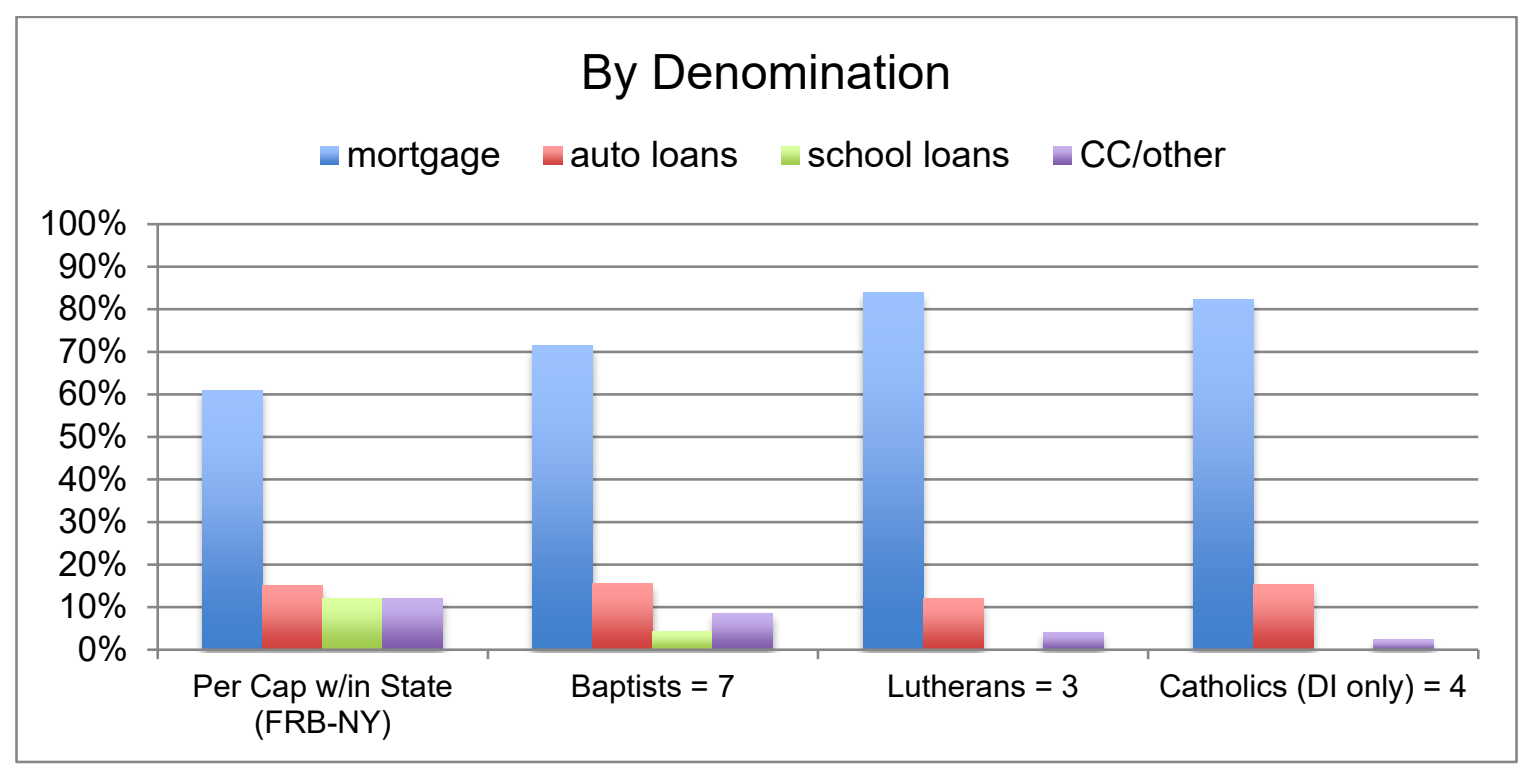

Source: Comparative data on the per capita distribution of debt within the focus state comes from the Federal Reserve Bank of New York's (FRB-NY) Quarterly Report On Household Debt and Credit 2019: Q1 (May 2019)

"Debt-to-income" ratios, based on current total household debt versus annual household income, are calculated for all (14) informants who hold debt and converted into percentages (see Figure 5). There is no clustering of informants attributed to any particular denomination. Rather, informants for each denomination are largely spread out across the overall group. The few informants with debt in excess of their incomes also represent all denominations, and the informant with the highest ratio is the only diocesan priest with a mortgage. Altogether, the majority of informants hold less debt than could be covered by their annual household income.

FIGURE 5

\section{HOUSEHOLD DEBT AS A PERCENTAGE OF ANNUAL HOUSEHOLD INCOME BY DENOMINATION}

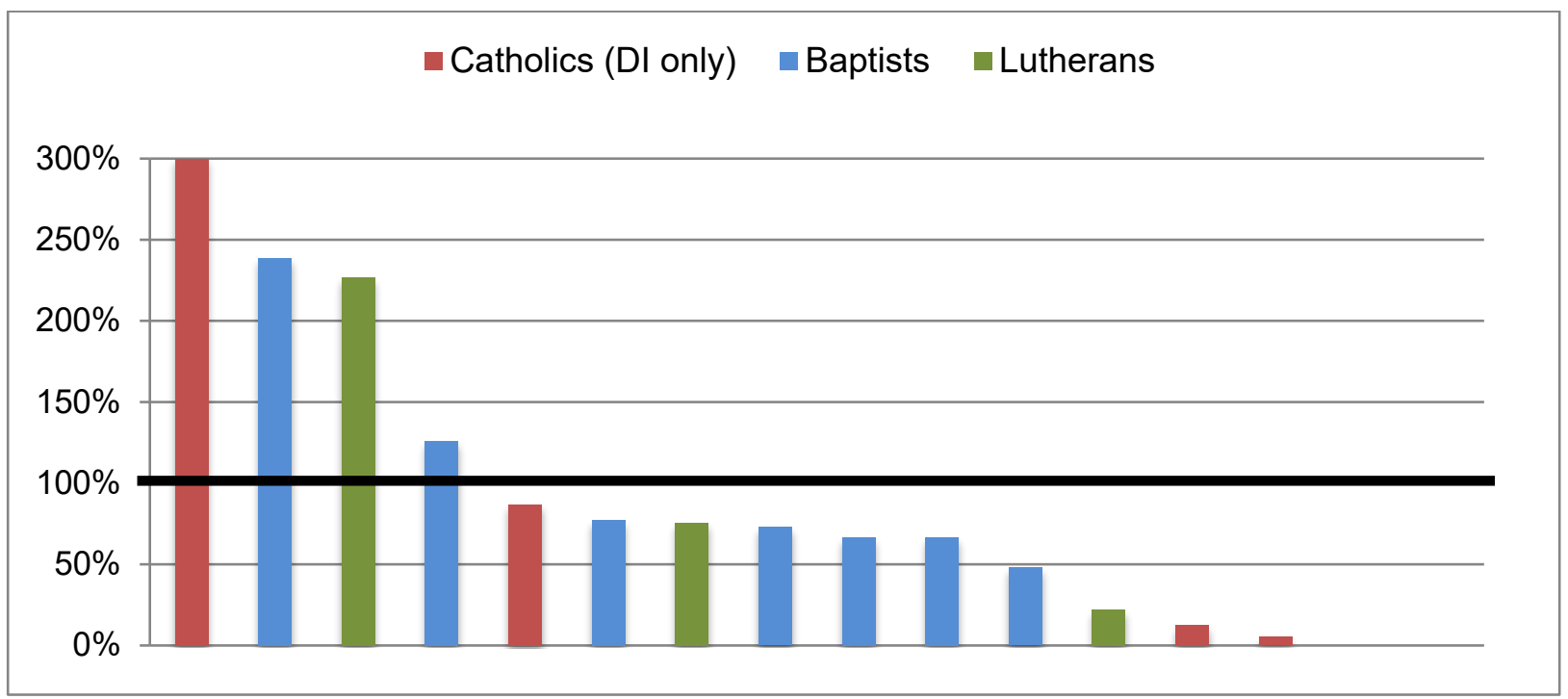

NOTE.--Marker line is used to highlight which informants have debt-to-income ratios above/below 100 percent. 
Next, a look at household debt relative to certain demographic variables, for example, age, race or ethnicity, and family structure. Figure 6 compares total household debt for each of the (14) informants who held debt to the $M_{\text {debt }}$ of the family head for their age group, as reported in the Federal Reserve's Survey of Consumer Finances [SCF] (FR-BOG, 2016). Survey respondents consist of adults aged 18 and older. The $M_{\text {debt }}$ for respondents initially increases with age, peaks for the group aged 45-54, and declines thereafter. Among clergy, one observation that does stand out is Daniel (B, age 64), who has a $\$ 300,000$ mortgage and $\$ 40,000$ in car loans. Otherwise, there is no obvious similarity between the national data and the small sample herein, for any denomination. Certainly, not enough clergy are included in this sample to identify a trend, and data for individual informants based on age over time was not collected.

Upon examining the $M$ and median household debt across races or ethnicities (in Figure 7), clergy display a very different relationship than what was reported in the broader SCF (wherein 6,254 families were interviewed). The median household debt for black clergy is the highest $(\$ 85,950)$, followed by Hispanic $(\$ 70,000)$ and then white clergy $(\$ 20,000)$. Note that the median and $M(\$ 81,00)$ for white clergy are quite different. According to the SCF, blacks and Hispanics each hold roughly half of the median household debt of whites $(\$ 74,100)$, with blacks $(\$ 31,100)$ only slightly above Hispanics $(\$ 30,000)$.

\section{FIGURE 6 \\ HOUSEHOLD DEBT BY AGE AND DENOMINATION}

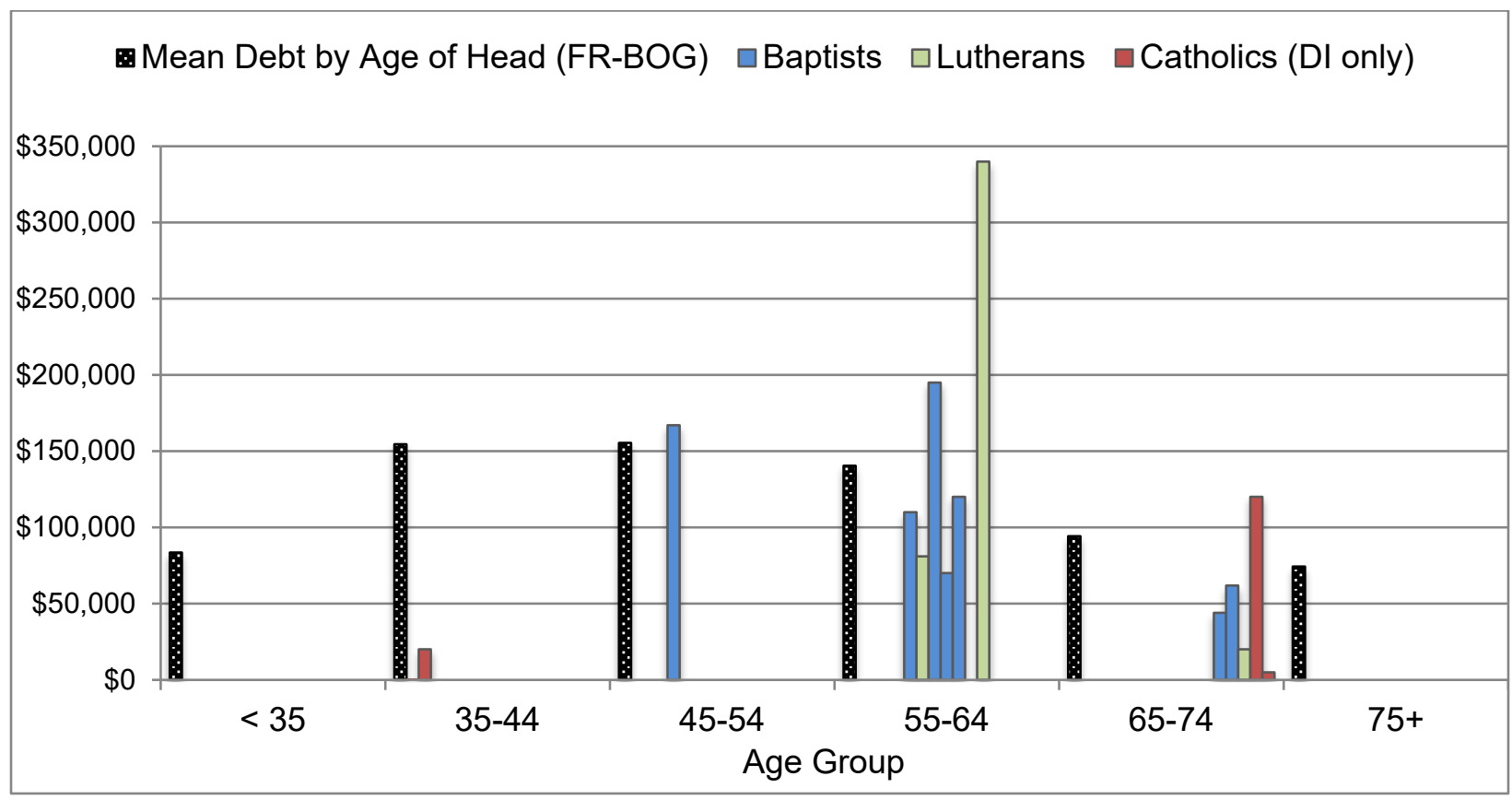

NOTE. - The report defines as head of the family "the male in a mixed-sex couple or the older person in a same-sex couple. If a single person is economically dominant, that person is designated as the family head." Source: Comparative data on $M$ debt by age of head comes from the Federal Reserve Board of Governors (FR-BOG) \& NORC Survey of Consumer Finances (2016). 
FIGURE 7

(MEAN VS. MEDIAN) HOUSEHOLD DEBT BY RACE OR ETHNICITY
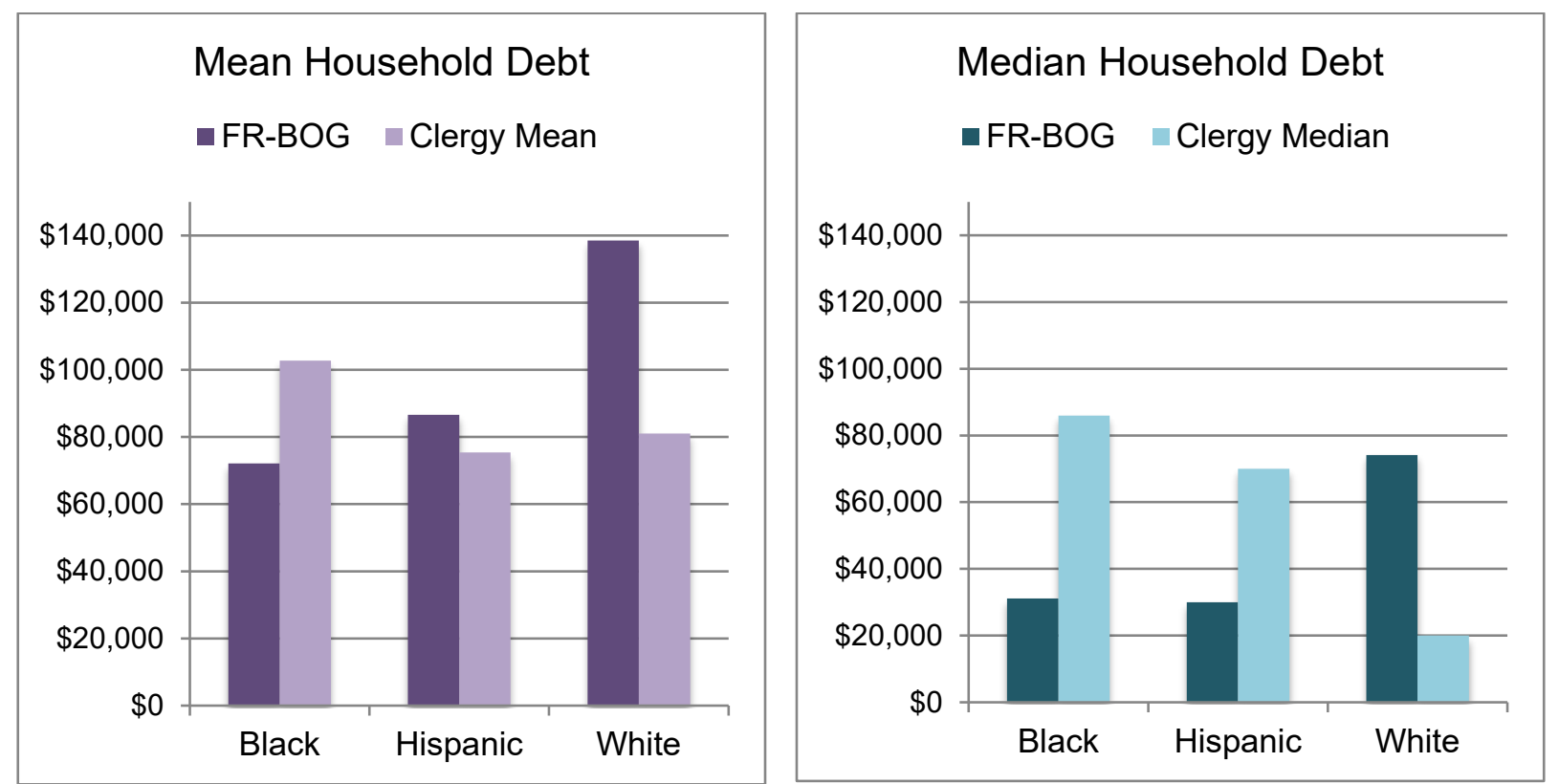

Source: Comparative data on $M$ and median household debt by race/ethnicity comes from the Federal Reserve Board of Governors (FR-BOG) \& NORC Survey of Consumer Finances (2016).

With regard to family structure, all married informants in this study are Protestant, and they all have children. However, only Scott (B), David (B), and John (L) would be classified as "couple[s] with child(ren)," according to the SCF, because each has at least one child (whether a minor or adult) who is financially dependent on them. In contrast, the remaining Protestants are classified as "couple, no child." In addition, Catholic informants are designated as "single, no child" and distinguished further according to age (see Figure 8). Within this total group of 16 informants, the median household debt for Protestants is above that of Catholics, consistent with SCF results for couples versus singles. However, debt attributed to Protestant empty nesters (the majority of whom were Baptist) exceeds that of Protestants with dependent children. Finally, the median household debt for Catholics below 55 years of age is less than for older Catholics. 
FIGURE 8

(MEAN VS. MEDIAN) HOUSEHOLD DEBT BY FAMILY STRUCTURE
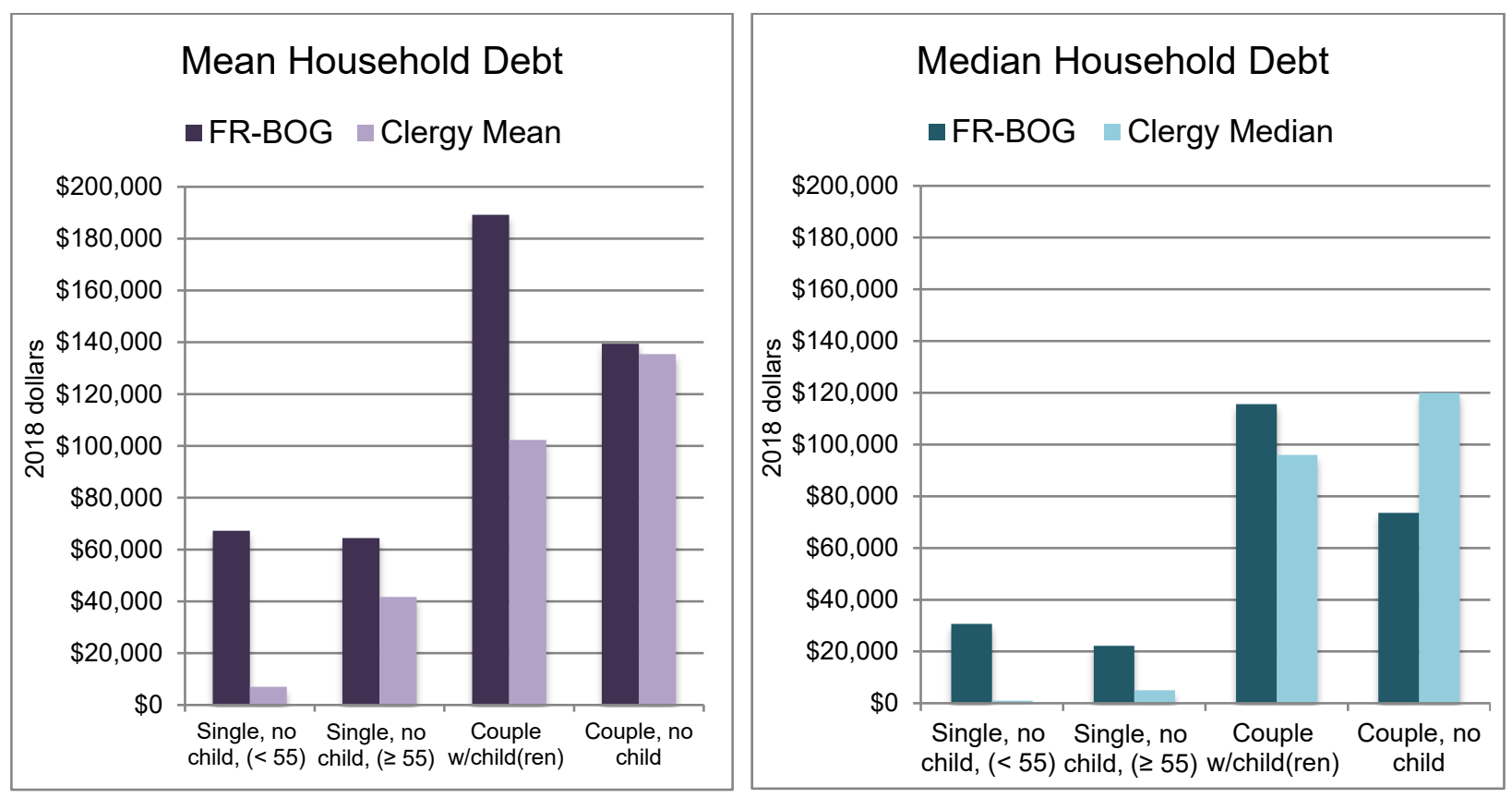

Source: Comparative data on $M$ and median household debt by family structure comes from the Federal Reserve Board of Governors (FR-BOG) \& NORC Survey of Consumer Finances (2016).

\section{ANALYSIS}

Informants' practices and experiences with credit/debt (shared in interviews) are analyzed in relation to the meaning patterns identified in the $\mathrm{P} \& \mathrm{~B}$ study, through to their resulting consuming subject positions (Figure 1). Each informant is initially evaluated according to his interactions in the social and market domains to derive that clergy member's overall meaning pattern. P\&B describe a group of levers on which opposing meanings rest that may tip toward a particular pattern of Doing the Right Thing (DRT) or Managing Debt, with Hybrid Combinations balancing somewhere in between.

\section{Clergy Evaluation}

Clergy Meaning Patterns

In contrast with the $\mathrm{P} \& \mathrm{~B}$ study, wherein the Hybrid Combination is most common, the most inclusive meaning pattern among clergy informants is DRT (with 10 cases). As noted in Table 3-A, this group represents all denominations, family structures, races/ethnicities, and covers a wide age range. Specifically, 
TABLE 3

INFORMANT PROFILES $(\mathrm{N}=16)$ *

\author{
A. Meaning Patterns
}

Doing the Right Thing (10) Hybrid Combination (6) Managing Debt (0)

\begin{tabular}{llll}
\hline \hline Denomination & $\begin{array}{l}\text { Baptists } \\
\text { Lutherans } \\
\text { Catholics (DI and RO) }\end{array}$ & $\begin{array}{l}\text { Baptists } \\
\text { Catholics (DI) }\end{array}$ & N/A \\
Marital/ & $\begin{array}{l}\text { Married with children } \\
\text { and Single }\end{array}$ & $\begin{array}{l}\text { Married with children } \\
\text { and Single }\end{array}$ & N/A \\
Age Ramily Status & $44-71$ (median =61) & $37-69$ (median = 55) & N/A \\
$\begin{array}{l}\text { Race/ } \\
\text { Ethnicity }\end{array}$ & $\begin{array}{l}\text { Black } \\
\text { Hispanic }\end{array}$ & $\begin{array}{l}\text { Black } \\
\text { White }\end{array}$ & $\begin{array}{l}\text { Hispanic } \\
\text { White }\end{array}$ \\
& & N/A &
\end{tabular}

B. Frequency of Meanings

$\begin{array}{lll}\text { Self-Discipline (10) } & \text { Freedom (6) } & \text { N/A } \\ \text { Independence (9) } & \text { Independence (2) } & \\ \text { Freedom (9) } & \text { Threat (1) } & \\ \text { Threat (4) } & \text { Self-Discipline (1) } \\ & \\ & \text { Social Integration (4) } & \text { N/A } \\ & \text { Indulgence (4) } \\ & \text { Security (2) }\end{array}$

\title{
C. Cultural Reproduction *
}

$\begin{array}{lll}\text { Normative (6) All Normalizing N/A } & \text { Al }\end{array}$

Normalizing (3)

D. Consuming Subject Positions *
All Efficacious
All Efficacious
N/A

NOTE. - * indicates Henry (RO) displays meanings characteristic of the meaning pattern, DRT, but is excluded from the cultural reproduction and consuming subject position counts because he has never used credit/debt.

Figure 9 shows that all Lutherans and religious order Catholics are DRT, as well as the majority of Baptists and some diocesan Catholics. The next prevalent meaning pattern is the Hybrid Combination (6). The racial/ethnic makeup and family status of this group is similar to DRT but includes most of the diocesan 
Catholics and the remainder of the Baptists. The median age for DRT (61 years) is greater than for Hybrid combinations (55 years). No informants display a pattern of Managing Debt.

\section{FIGURE 9 \\ CLERGY MEANING PATTERNS}
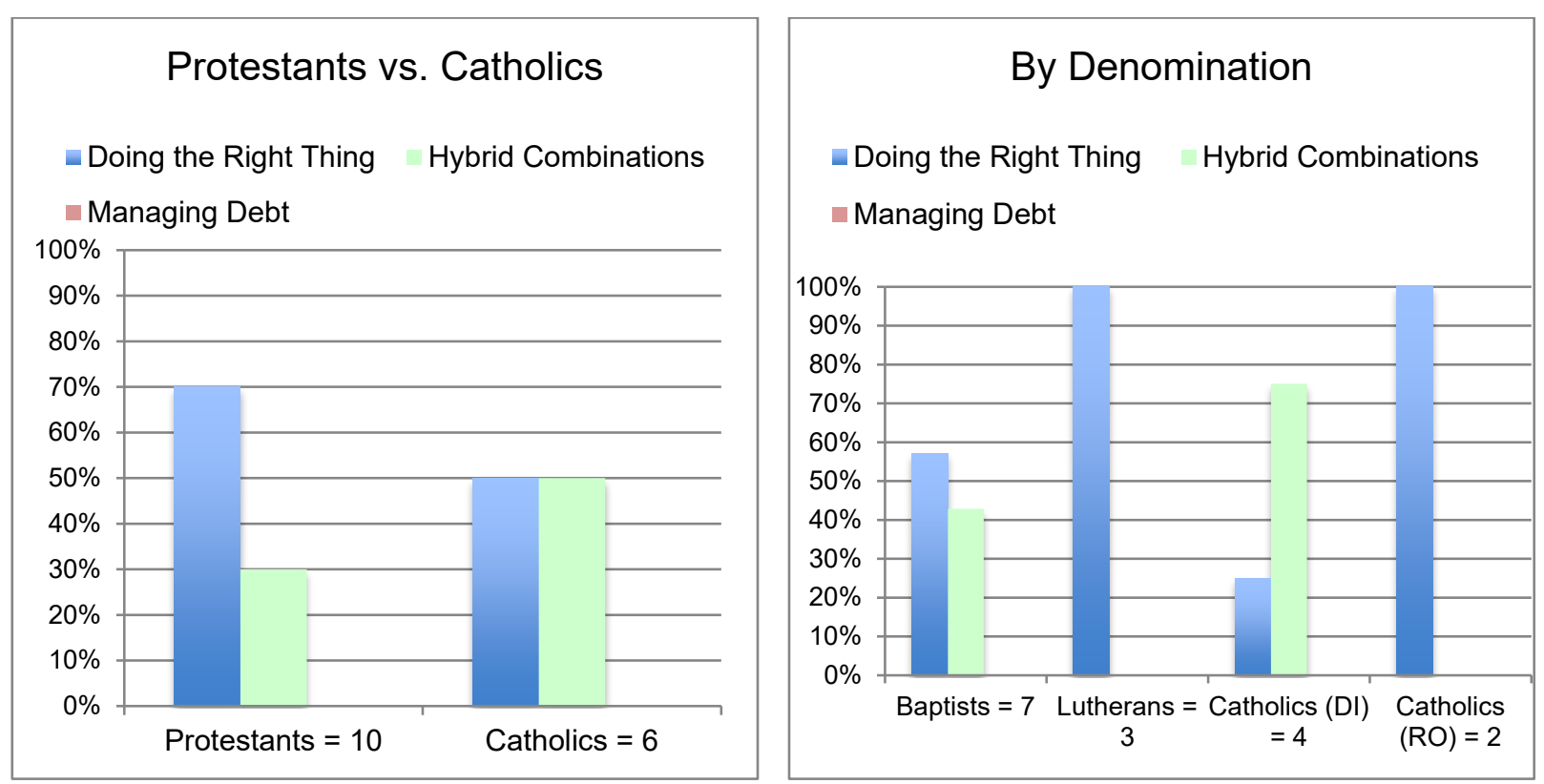

Attention is also given to the frequency of meanings across all informants, in relation to the three meaning patterns (Table 3-B). Perhaps not surprisingly, the meanings attributed to DRT all rank highly among informants displaying this pattern, with self-discipline, independence, and freedom as most prominent, and viewing credit/debt as a threat (rather than security) as the least. Informants exhibiting Hybrid Combinations share some of the same meanings as DRT. (Attaining freedom to access additional credit/debt in the marketplace seems to play a role across informants, regardless of their pattern.)

However, for Hybrid cases these are offset by tendencies toward meanings associated with Managing Debt. For instance, using credit/debt for social integration (versus exerting one's independence) and indulgence, as well as viewing credit/debt as security. Threat and self-discipline are least common in Hybrid combinations.

Within this group of informants, Scott is featured as an example of a Hybrid Combination and Albert to illustrate the meaning pattern DRT. They have several traits in common. Both are Baptist clergy (affiliated with the SBC), are married with children (only Scott's child is financially dependent) and are near the same age, but of different racial/ethnic backgrounds. Scott is 50 and black, whereas Albert is 59 and white. Scott has an annual household income of $\$ 165,000$, and his household debt is $\$ 130,000$ (including a \$20,000 student loan.) Albert's household income and annual household debt are \$250,000 and $\$ 120,000$, in turn.

Scott's (B) overall profile consists of debt spread out across all types, including a student loan (belonging to his wife). In addition, although he has the second highest household income, his "debt to income" ratio is equivalent to the median for all informants. By definition, informants exhibiting a Hybrid pattern display a blend of meanings across DRT and Managing Debt. In some cases, there are particular meanings that serve to balance one another. Scott's ability to access additional credit is not constrained (he enjoys this freedom). However, he does express attitudes toward credit/debt characteristic of Managing Debt. Relative to other informants, Scott's meanings are weighted partly toward indulgence and social 
integration, but he has no strong leanings when it comes to viewing credit as security or threat. Consequently, Scott's meanings form a Hybrid Combination.

While Scott budgets according to what he refers to as the "biblical principle" or 10-10-80 rule (of giving, spending, and saving), regularly pays more than the monthly minimum on his credit cards, and says that he tries to spend "intelligently," he confesses to being a "bigger spender" than his wife. He also admits that what "kills" him is "splurging on vacations" and that his car loan is the result of "emotions" and "hype."

Given Scott's tendency to use credit/debt for social integration and indulgence, it is worth noting that he may be counting on the additional sources of income he expects to receive upon retiring. Beyond what he will receive as a clergy member, he is the beneficiary of a relative's pension and will also draw on his own pension from a previous career.

Albert (B) embodies most fully all of the meanings inherent in the pattern of DRT (i.e., independence, self-discipline, threat, and freedom). He is also the only millionaire among clergy informants (with a net worth of around $\$ 4$ million) following the sale of a successful 20 -year business nearly a decade ago. He has used credit/debt primarily to purchase homes and cars, and credit cards for "convenience." Regarding credit cards, he notes, "I literally put almost everything on them," but consistently pays them off in full each month. He describes himself and his wife (even more so) as "debt adverse" and warns, "people rely too much on credit and debt" and "they don't realize what they're doing. Basically, they're putting themselves in bondage. And you become a slave." In his own right, he admits to learning some hard lessons from his first home purchase, including being left with only $\$ 50$ in his bank account and having to accept help from family.

Scott and Albert differ most in their long-term outlook on debt. In short, Scott assumes that debt (for him) will always be there "in some form or fashion" but believes he will be alright as long as it is "controlled" and he can afford to pay off his credit cards:

I always want to try to keep our/my credit cards, uh, with-I call it, within striking distance. And that means, if I just had to, I could, you know, go to our-my savings and may take all the money out of them. But I could take it out and pay it off. (Scott, B)

Lastly, Albert paid his debts off fully twice before and plans to do so again, operating under the belief that one should be completely out of debt by retirement.

\section{Clergy Consuming Subject Positions}

As per $\mathrm{P} \& \mathrm{~B}$, "the construct consuming subject position encapsulates the reality effects on consumers of the meanings they produce in credit/debt" (2011, p.755). For instance, DRT will result in an efficacious consuming subject position. Hybrid Combinations may also yield an efficacious, or compromised, position. Finally, those who are Managing Debt may end up compromised, or even punished as consumers. All clergy informants displaying a pattern of DRT or a Hybrid Combination are found to be efficacious (Table 3-D).

As was noted in the earlier introduction to the model, P\&B identified self-discipline and viewing credit/debt as a threat as key to generating an efficacious outcome. Of the 16 clergy informants who display either DRT or a Hybrid meaning pattern leading to an efficacious outcome, self-discipline is indeed widespread, in line with using credit/debt to exert independence (11 instances of each). However, freedom (15 cases) surpasses them both, and only five informants see credit/debt starkly as a threat. In fact, the collection of meanings that most often leads to an efficacious outcome for clergy informants includes independence, self-discipline, and freedom (9 cases).

No informants are categorized by and large as compromised in their consuming subject position (i.e., subject to higher fees, interest charges, or poor credit ratings, etc.), but Bruce (DI) remarks on one aspect of compromise. Though he exhibits a Hybrid combination with an efficacious outcome-balancing mild tendencies toward social integration and indulgence with threat and freedom-he does mention being subject to higher interest rates (than his brother) due to his relatively limited credit history. No informants are constrained to the point of being punished. 


\section{Clergy Trajectories}

Recall that the P\&B model is dynamic, and individuals can move from one meaning pattern to another over time, via certain trajectories. Therefore, it is possible that clergy informants could have been classified differently at other points in their life. For instance, Albert (B, age 59) long ago experienced a home foreclosure, albeit as a consequence of someone else's bankruptcy. He owner-financed his first home to someone who claimed to be paying the mortgage company directly, but was not. When the buyer declared bankruptcy, the bank foreclosed on the home, leading Albert to lose roughly $\$ 15,000$. Nick (B, age 54) also went through a foreclosure and a bankruptcy. During the last recession, he had "got into a mortgage with no down payment... at $8.9 \%$." Fortunately, he has since received "a document where they said... the bankruptcy was something they take out my plate... and considered that was a wrongdoing from the financial company." In some sense, both Albert and Nick "learned their lesson" and have been adamant about avoiding these types of situations ever since.

Another informant, Andrew (DI), appears to be on the verge of a change in meaning pattern. He has meanings in credit/debt that resemble a Hybrid pattern and his position as a consumer is efficacious. Though, he more recently has shown evidence of "charging away," which could potentially lead to Managing Debt and finding himself in a compromised position. He indulged by borrowing $\$ 20,000$ (nearly equivalent to his annual salary) to purchase a brand a new car following an accident. The decision is uncharacteristic of his interactions with credit/debt to date. Even with his earlier tendency to rely on family members for assistance with his student loan debt (i.e., social integration), he is not constrained from accessing additional credit. Rather, he is paying above the minimum required payments on his vehicle. Andrew exemplifies an informant who might benefit from being alerted to the possible, long run consequences of his actions to help maintain his status as an efficacious consumer.

\section{Clergy Cultural Reproductions}

In order to classify informants' consumption ethic as "normative," "normalizing," or "marginalizing," clergy members' definitions of credit and debt, the rules they invoke, their practices (e.g., repayment habits), and the incentives that affect their use of credit/debt are examined.

The results of this study most closely approximate $\mathrm{P} \& \mathrm{~B}$ in this area. DRT often leads to normative cultural production and that all Hybrid informants are normalizing credit/debt (Table 3-C). In addition, this is consistent with $\mathrm{P} \& \mathrm{~B}$ 's caveat that some degree of normalization can be seen across all informants.

As illustrated in Table 4, less than half of clergy informants (6) reflect a normative cultural production expressing "what they and others should (not) do" (P\&B, 2011, p.755). This group includes only informants who are DRT and efficacious, and represents a mix of denominations: all religious order Catholics and a majority of Lutherans, as well as some Baptists and diocesan Catholics. In addition, the median age is older (64) and informants are white, with the exception of one Hispanic.

Informants expressing normative views generally apply a principle that governs their purchases and consequently, their use of credit/debt. For instance, Albert (B) cautions not to "overspend," or as Daniel (L) elaborates, "don't spend more than you make." Whereas, Sam (RO) and Mike (DI) state simply, if you "don't need it, don't buy it." Further, Jake (L) and Nick (B) emphasize the importance of having a plan for paying debt. Though all informants in this group use credit cards, they pay them off monthly.

Also, most are in some way working toward satisfying their debts by retirement, if they have not yet done so. When asked what they thought was worth borrowing for, nearly all said either a house or a car, and in some cases, to help with medical expenses. (As a former businessman, Albert (B) would only borrow for another building to generate income.) Views among the group are mixed on whether a mortgage or a student loan is an investment/credit, "good" debt, or simply debt.

Another set of informants, also DRT and efficacious, is instead normalizing credit/debt. In comparison with the previous group, John (L) and Eric (B) follow more specific rules in relation to credit/debt. John has been meeting with a financial advisor and tried to limit his debt (including his house payment) to no more than 30 percent of his income. Eric is employed in the financial sector and works at keeping his credit card balance within 19 percent of his credit limit. He is not sure if it was a good idea to completely pay off his debts because, as he notes (in regard to creditors), "they've got nothing to judge you on." Both Eric and 
John assign some level of importance to maintaining their FICO scores and are inclined to roll over debt. On the other hand, Steve (B) pays off his credit card each month, but follows no particular rules. He also quickly satisfied his daughter's $\$ 30,000$ in student loans by delegating bonuses from his private sector job and taking advantage of zero percent interest credit cards. Although he considers "too much" debt to be "bad," he views credit and debt as necessities, and obtaining a mortgage as the only way to buy a house (as does Eric).

TABLE 4

INFORMANT OUTCOMES

\begin{tabular}{lllll}
\hline \hline $\begin{array}{l}\text { Name } \\
\text { (Pseudonym) }\end{array}$ & Religious Affiliation & Meaning Pattern & Cultural Reproduction & $\begin{array}{c}\text { Consuming } \\
\text { Subject Position }\end{array}$ \\
\hline & & & & \\
Albert & Baptist - SBC & DRT & Normative & Efficacious \\
Nick & Baptist - SBC & DRT & Normative & Efficacious \\
Daniel & Lutheran - ELCA & DRT & Normative & Efficacious \\
Jake & Lutheran - ELCA & DRT & Normative & Efficacious \\
Mike & Roman Catholic (DI) & DRT & Normative & Efficacious \\
Sam & Roman Catholic (RO) & DRT & Normative & Efficacious \\
Henry $*$ & Roman Catholic (RO) & DRT & N/A & N/A \\
John & Lutheran - ELCA & DRT & Normalizing & Efficacious \\
Steve & Baptist - SBC & DRT & Normalizing & Efficacious \\
Eric & Baptist - N/A & DRT & Normalizing & Efficacious \\
George & Baptist - NBCA & Hybrid & Normalizing & Efficacious \\
Scott & Baptist - SBC & Hybrid & Normalizing & Efficacious \\
David & Baptist - CBF & Hybrid & Normalizing & Efficacious \\
Bob & Roman Catholic (DI) & Hybrid & Normalizing & Efficacious \\
Andrew & Roman Catholic (DI) & Hybrid & Normalizing & Efficacious \\
Bruce & Roman Catholic (DI) & Hybrid & Normalizing & Efficacious
\end{tabular}

NOTE.- * indicates Henry (RO) displays meanings characteristic of the meaning pattern, DRT, but is excluded from the cultural reproduction and consuming subject position counts because he has never used credit/debt.

Overall, Figure 10 shows that more clergy (9)—Protestant and Catholic alike-are normalizing credit/debt. The previous three informants notwithstanding, this group reflects mostly Hybrid combinations. Altogether, it is comprised of the vast majority of Baptists and diocesan Catholics, and one Lutheran. The median age for this group is slightly younger (58 years) and informants are black (4), Hispanic (3), and white (2).

Rolling over credit card debt is not uncommon for those normalizing credit/debt. Baptists George and Scott make a habit of this practice, but emphasize that they pay on time or more than the required monthly minimum, respectively. George also speaks generally about the importance of FICO and improving one's credit score. Bruce (DI) occasionally rolls over his credit card debt but tries to keep it at no more than "\$200 tops." Some informants go so far as to conclude that living a life in debt is inevitable. According to George, that is "...cause my father-in-law, who's a very wise man, told me... you gonna always owe somebody." Scott simply expects debt will always be there "in some form or fashion."

In some cases credit is seen as a valuable reflection of whether one is "worthy," as Bob (DI) notes. To that end George advises, "get as much credit as you can, but minimize your debt... when your credit is 
good, your score's good." David (B) and Bruce (DI) also see the positive aspects of credit. According to David, it can be "something that will improve your life." He refers not only to the ability to buy a house or car, but also appliances and furniture. Bruce includes vacations and "luxury items" as "things that you need for life" and worth borrowing for. In addition, both concede to needing to have a plan for debt. On the whole, informants normalizing credit/debt are consistent in considering a house and/or a car worth borrowing for, but have differing opinions on student loans. For instance, David warns, "educational debt can ruin you."

\section{FIGURE 10 \\ CLERGY CULTURAL REPRODUCTIONS}
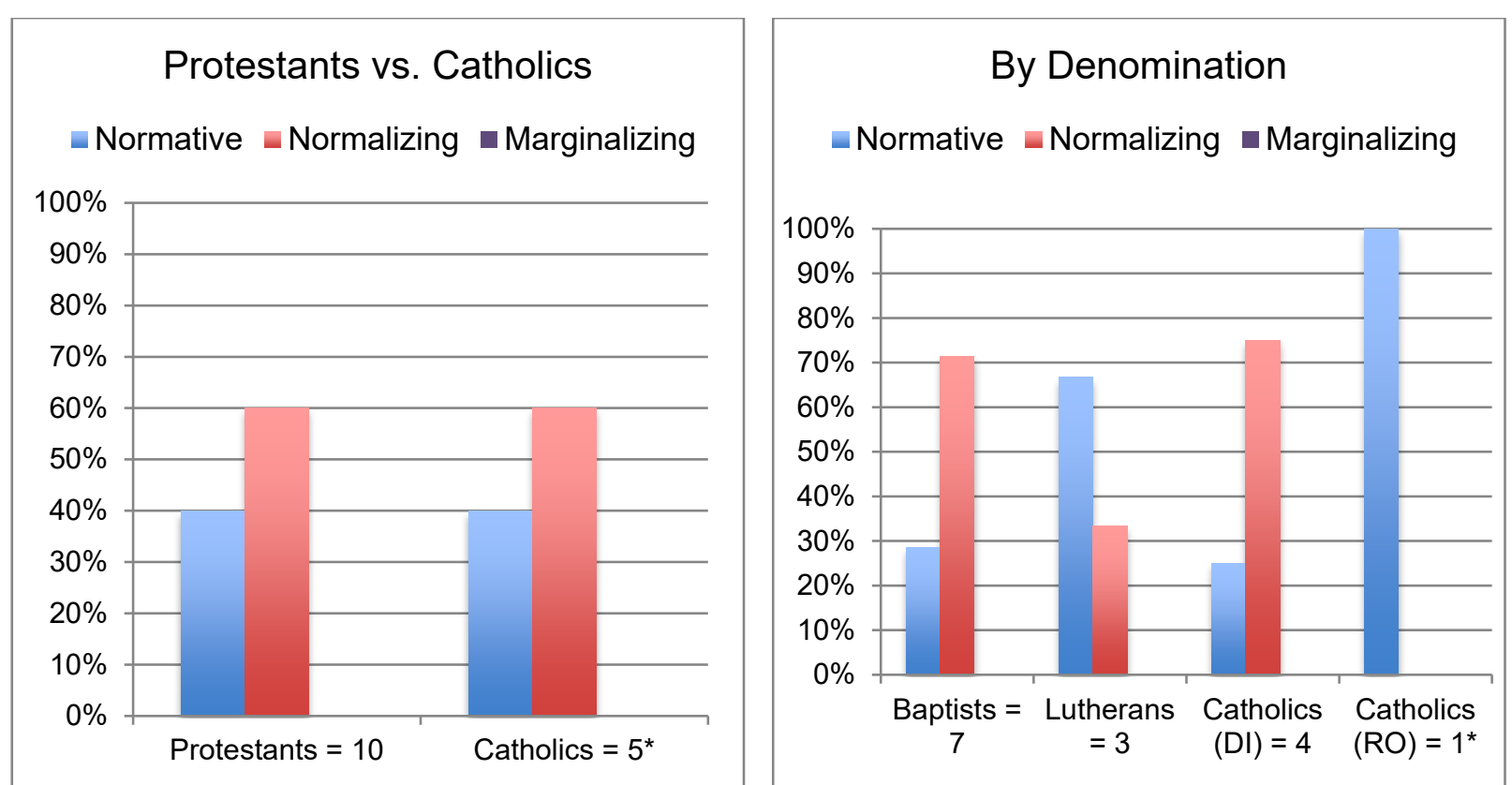

NoTE._* indicates Henry (RO) is excluded from the cultural reproduction counts because he has never used credit/debt.

Andrew (DI) and Henry (RO) are somewhat difficult to categorize. Andrew has never used a credit card and has less experience with debt relative to his peers in this group (i.e., a previous student loan and now a car loan). Further, the outlook he expresses is similar to that of normative informants when he states, "if you don't have money to, why go get something," and he normally plans out his purchases. However, his recent indulgence in a new car, costing nearly as much as his income, is proving to be a challenge for him and seems to contradict this view. (Granted, he may feel that he could once again rely on family members to assist with payments as they did with his student loan.) Hence, he is classified as normalizing credit/debt. Henry presents a unique case among clergy informants. He displays meanings that together form a pattern of DRT, but his complete lack of experience or interaction with credit/debt fails to provide any information pertaining to heuristics or own practices. Consequently, it cannot be said (in the same manner as was the case for other informants) whether he is normalizing credit/debt. He remains unclassified in his cultural production and consuming subject position.

On a broader scale, one might be inclined to say that all informants are to some extent normalizing credit/debt through their use of credit cards (save Henry and Andrew, since they never have possessed a credit card). Those with credit cards repeatedly comment on the various perks they receive, such as earning miles, or points, and money back. Bob (DI) "puts everything I can on the credit card because I wanna get the miles," and Jake (L) does the same "because we're trying to get [airline] points now." Diocesan priests Bruce and Mike also earn points, “... and I enjoy that" (Bruce). Alternatively, a credit card is an "advantage" 
to Steve (B) because it "pays me to use it," returning around " $\$ 800$ per year." Nick (B) gets $1 \%$ cash back on his card. In addition to money back, Sam (RO) values the "better protection" and insurance coverage he receives during his monthly travels. Albert (B) emphasizes the "convenience" of using a credit card. According to Steve (B), credit cards are "like cash now." Moreover, David (B) likes the ability to "track everything," and Sam (RO) agrees, particularly for reimbursement of parish-related expenses.

Housing tax benefits and interest rate arbitrage may also be serving to normalize debt and are cited as reasons that informants do not necessarily think it worth getting out of debt. According to the Internal Revenue Service (IRS), "a minister's housing allowance... is excludable from gross income for income tax purposes" (2019). For this reason, informants David (B) and John (L) are hesitant to ever pay off their mortgages. Jake (L) and Bob (DI) have exclusively mortgages as debt and the means to pay them off today, but have chosen to carry this debt because of a clergy tax benefit. Jake elaborates on his situation:

The only debt we have is, I still have four years to pay on my house. But with clergy, getting tax benefits for a housing allowance. We're, we have a similar thing to the military. We're advised, you're probably smart, if you're gonna have a debt, have it your house, because you're gonna want to put money into housing that has some tax advantage to it. So it's a debt, yes. But. I have $\$ 20,000$, and I've got $\$ 50,000$ in a savings account. So I could wipe that out and say okay, I'm debt free, so. Yeah, I'm carrying a debt because it's to a tax advantage, if that makes sense, to have that pay. Now, what we're gonna do in four years. We may have to buy another house. Or buy something. [...] So, I will probably always have, uh, some housing debt, because that's. And my [inc.] pension plan is set up for everything we draw out of it, can be counted toward housing, for IRS purposes. So that's a nice deal. So it's a little different with clergy. Some clergy.

Bob (DI) also believes "it doesn't pay me to pay off my condo debt," albeit for a different reason. He has an annuity that earns more in interest than he pays (in interest) on his mortgage. Consequently, although he could use his annuity to pay off his mortgage now, he would be giving up the difference. Daniel (L) is in a similar predicament.

Finally, no clergy informants are classified as marginalizing. This could be because none of them are Managing Debt and in a punished consuming subject position. As noted earlier, P\&B identified marginalizing informants as exclusive to that particular outcome.

In sum, by applying the $\mathrm{P} \& \mathrm{~B}$ framework to interpret clergy attitudes toward credit/debt, it happens that the majority of clergy display traits culminating in a pattern of DRT, followed by Hybrid combinations. Further, all informants yield efficacious consuming subject positions, and the normalization of credit/debt is commonplace. Subsequently, patterns unique to clergy are explored and similarities or differences highlighted, between Protestants and Catholics as well as across denominations.

\section{Other Patterns Among Clergy}

Beyond evaluating clergy through the lens of the P\&B model, the analysis of the interview data herein also revealed various incentives particular to clergy in regard to their handling of finances and attitudes toward credit/debt. For example, the call to tithe has created an incentive to budget among a number of Protestant informants who consequently abide by the 10-10-80 rule. Referring to it as the "biblical principle," Scott (B) defines the rule as "10 percent to God, 10 percent to self for saving, 80 percent to live off of." Steve (B) learned the rule from his pastor, and Daniel (L) thought it "would be a [good] goal" and tried to "move into that... pattern" after a "a stewardship talk at a Lutheran church," while Jake (L) chooses to set aside $11 \%$ of his income for tithing. At the same time, Protestant and Catholic (DI) informants alike are encouraged to remain in considerable (mortgage) debt due to clergy tax benefits on housing. As noted earlier, this can contribute to clergy normalization of debt.

As pastors, clergy also are in a key position to influence others as they offer counsel to their congregants/parishioners. In fact, several Protestant clergy readily admit to volunteering financial advice. For instance, Scott (B) shares how he handles his finances and instructs others on the 10-10-80 principle. 
Some clergy have ties to the financial sector as well. As a former employee of a financial services company, Steve (B) gives advice freely to "anyone that wanna listen" on "how to get outta debt [...] how to save for retirement $[\ldots]$ and how tithing could bless you." Further, he has held classes for church members on how to handle money with books from personal finance courses that he took. Eric (B) works in the financial services sector and generally shares advice with friends and his children on how to maintain a good credit score. However, he shares a cautionary tale on how financial advice may not always be accurate. In his case, he received "bad advice" on credit from a friend at work who recommended that he "pay the minimum and not to pay off." In retrospect, he admits that he "listened to him and that wasn't very smart." Jake (L) also tries to share advice with other pastors, because a lot of people are coming out of seminary "deeply in debt."

\section{Denominational Comparisons}

Since Baptist, Lutheran, and Catholic (DI ad RO) informants are included in this study, this offers an opportunity to examine further similarities or differences within this group of clergy. One obvious basis for comparison is the differing family structure between Protestants and Catholics and whether this has any apparent connection to clergy outcomes. Earlier denominational findings are also supplemented with data on race or ethnicity to see what other patterns might arise across denominations.

\section{Family Structure}

Catholic informants have all taken a vow of celibacy and therefore are not married, nor do they have children. In contrast, Baptist and Lutheran informants are all married and have had, or are raising, children. Certainly, life events involving marriage and children can introduce additional financial pressures, not limited to negotiating finances with one's spouse, dealing with family emergencies, and paying for college. In fact, several Protestant clergy disclosed how they wrestled with these issues.

For Daniel (L), the experience of being newly married caused some financial distress. He recollects how his wife came with "maxed out credit cards" that they had to pay off before being stationed overseas. He explains how "army officers are not allowed to bounce a check at all" and otherwise "would be subject to... blackmail or... coercion from foreign agents." Nonetheless, he contends that he has since "persuaded her to go along [with him]," and that she is "coming around." In addition, David (B) felt "several times" that his debt was a challenge. For instance, when his first spouse accumulated $\$ 10,000$ in debt "mostly on furniture," the period during which his current wife was a "stay-at-home mom," and more recently, having to spend $\$ 10,000$ toward an "emergency surgery" and braces for his children.

Educational expenses have also contributed to some tough financial times for John and Steve. Not only have John (L) and his spouse taken out additional loans to help their children with college, they are postponing major purchases, for example, "home upgrades," and looking for additional sources of income. In addition, at one point, Steve (B) found himself paying hefty interest on a $\$ 30,000$ loan for his daughter's schooling. However, he "knew that I needed to get out of it," that "it was just a waste of money." Consequently, he worked to pay off the full debt in four years using bonuses from work and taking advantage of $0 \%$ interest credit cards.

However, the manner in which clergy informants' meaning patterns break down does not appear to play out according to differing family structures. In spite of the aforementioned pressures, a greater proportion of Protestant informants are DRT versus Hybrid combinations, and Catholics are split between these meaning patterns (see Table 4). Moreover, along denominational lines, Lutherans and religious order Catholics are most similar in DRT, along with the majority of Baptists.

Regarding Lutheran clergy, the ELCA is particularly concerned with promoting financial literacy and is actively working to provide counseling and incentives. Toward that end, the church launched the "Resourceful Servants" program in 2017. The initiative addresses in part the "lack of emergency savings and retirement savings." John (L) is a participant of the program, which requires that he meet twice with a financial planner. Consequently, he receives an additional 1 percent match on his retirement contributions and has been encouraged to put more funds aside. Jake (L) also referenced the program and says that he tries to give similar advice to other pastors as well. 
On the other hand, tendencies toward social integration and indulgence yielded Hybrid patterns for most diocesan Catholics and remaining Baptists. Although it is a widely held belief that priests exit seminary with no debt, Catholics are also prone to financial challenges. For example, Bruce (DI) was most burdened by debt toward the end of seminary. Here he elaborates on how things got out of control, but eventually turned around:

I was really starting to get nervous. Um. And just kind of [inc.] myself. I think I had been in that place where I was like, well, I'm fine. You know, they're paying for school, duh, duh, duh. And I-I think maybe that attitude rolled over into [inc]. I don't know. I don't know what I was thinking. And so, towards the end of seminary, when I looked at my credit card statements thinking, [inc.] just been servicing this debt and not really going anywhere. It's just getting bigger and bigger. Um. Not necessarily ballooning, but enough to be nerveracking. And, um. I don't know. I just, I-I felt rather foolish, uh, and a little, um, intemperate. You know, just kind of feel like I wasn't in control of my spending. [...] Um. Luckily, um, my financial situation changed with ordination and I was able to, to handle it. But. It would've been nice to not have to handle that my first year of priesthood. [...] I did end seminary with about $\$ 5,000$ worth of credit card debt over the 6 years I-I [inc.] Um. And that was a bit scary. Um. But people were generous at ordination and I worked hard my first paychecks to-to pay that down. So by the end of the first year, I was, I had retired the debt, and [Laughter] then bought a car. [Laughter.] So [inc.] debt back. But, uh. But I was in good shape by the end of the first year. (Bruce, DI)

As for the further disparity in meaning patterns among Catholic diocesan and religious order priests, perhaps Mike's (DI) comment offers some additional insight. He explains, "most of us who are diocesan have to buy our own cars. Whereas a religious order, they get it free. So we're given a salary. We have to provide for our retirement as well."

\section{Race or Ethnicity}

In contrast with $\mathrm{P} \& \mathrm{~B}$, a unique feature of this study is that the informants come from different racial or ethnic backgrounds (i.e., black, Hispanic, and white). Consequently, the denominational findings on clergy meaning patterns and cultural reproductions are reexamined together with data on race or ethnicity. As shown in Table 5, all white informants, excluding Bruce (DI), are DRT. Further, these informants are spread across all denominations. Black informants - all of whom are Baptist - are split between DRT and Hybrid meaning patterns. Hispanics — whether Baptist or Catholic - are also split between these two meaning patterns. Lastly, most white informants, as well as one Hispanic (Nick, B), are inclined toward a normative cultural reproduction.

Overall, P\&B found that the majority of their white middle class informants demonstrated Hybrid meaning patterns and were for the most part normalizing credit/debt. Instead, nearly all of the white clergy informants are DRT and display a normative cultural reproduction. When this is coupled with denominational data, it becomes evident that Lutheran and Catholic (RO) clergy are predominantly white and all DRT. The inclusion of black and Hispanic clergy, who are mainly Baptist and Catholic (DI), introduces more Hybrid combinations and more normalization of credit/debt.

While these comparisons are interesting, they involve a limited group of clergy and the largest race or ethnicity represented is white, which makes it difficult to identify true patterns across black or Hispanic clergy. To determine further whether patterns exist based on race or ethnicity, or denomination (or both), it would be helpful to have comparative data on the racial/ethnic distribution of clergy by denomination. However, this data was available only for members (within the focus state) from the Pew Research Center (2014) and the ELCA (2017). As such, the ELCA and Catholic informants reflect the racial or ethnic distribution of their denomination's members; predominantly white (ELCA) and mostly white and Latino (Catholics). On the other hand, this would mean that blacks are overrepresented among the Baptist 
informants. Four of seven Baptist clergy are black, but the majority of these Baptists are affiliated with $\mathrm{SBC}$. The $\mathrm{SBC}$ and the $\mathrm{CBF}$ are mainly white, while the NBCA is predominantly black.

TABLE 5

CLERGY MEANING PATTERNS AND CULTURAL REPRODUCTIONS BY RACE OR ETHNICITY AND DENOMINATION

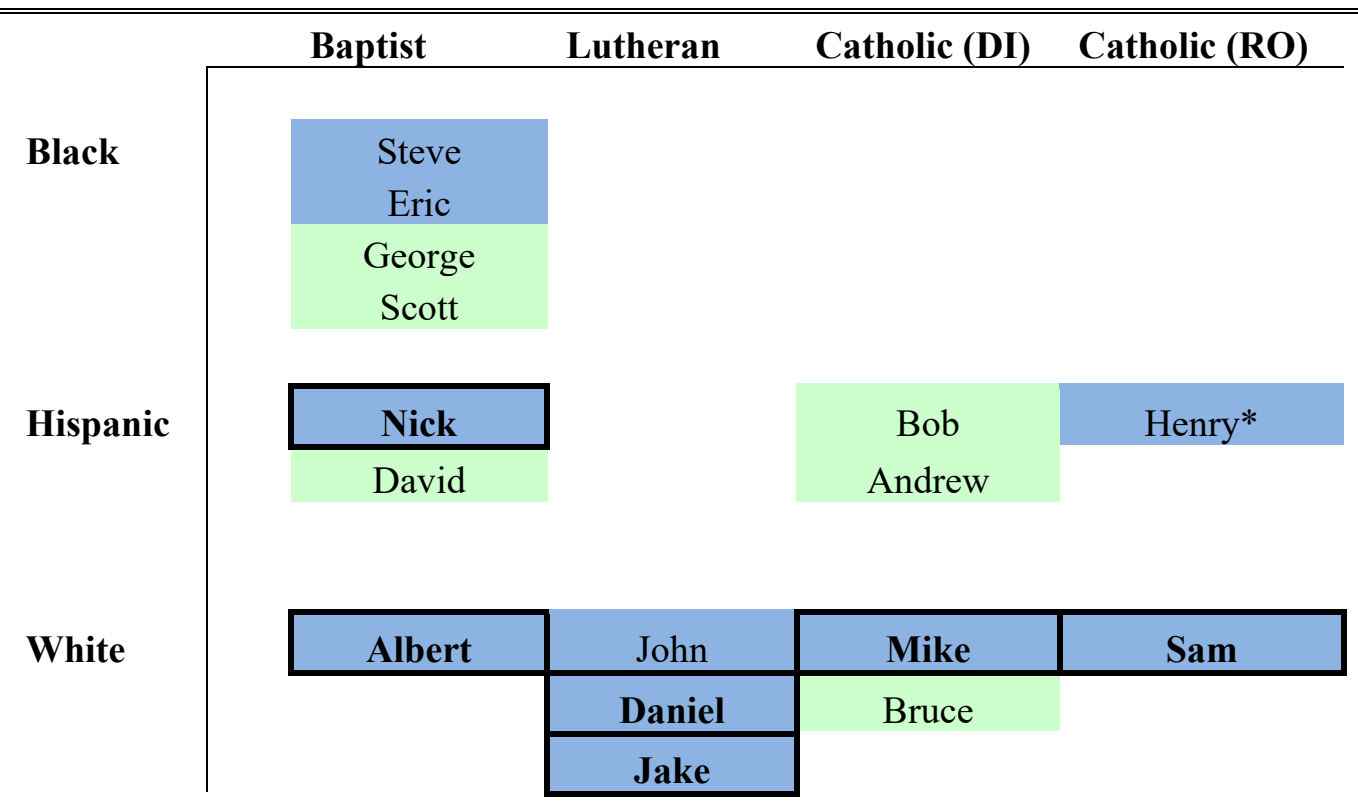

NOTE.-Blue cells = DRT meaning pattern; green cells = Hybrid meaning pattern; outlined cells with names in bold denote informants DRT and demonstrating a normative cultural reproduction; * indicates Henry (RO) is excluded from the cultural reproduction counts because he has never used credit/debt.

\section{CONCLUSION AND AVENUES FOR FURTHER RESEARCH}

This study draws on earlier research conducted by Peñaloza and Barnhart (2011) on the normalization of credit/debt among the U.S. white middle class. More specifically, the framework of the P\&B model is used to identify attitudes toward credit/debt among ordained Baptists, Catholics, and Lutherans of different racial or ethnic backgrounds. In addition, patterns prevalent among clergy are explored and comparisons made across denominations.

It has been shown that clergy clearly engage in the use of credit/debt, including even some religious order priests. Most clergy also carry a variety of types of personal debt, much like non-clergy, and are exposed to similar influences that promote staying in debt and the normalization thereof. Further, clergy are prone to experiencing life events in different forms or to varying degrees in accordance with their family structure (depending on whether they are Protestant or Catholic). Though these changing circumstances could drive individuals into charging away or simply easing into debt, informants seemed determined to work through these challenges. In fact, at least among this group, clergy are generally DRT and efficacious as consumers. Still, the presence of Hybrid combinations reveals that tendencies toward Managing Debt can creep in (e.g., social integration and indulgence) and may be worth monitoring.

In addition, the results demonstrate that clergy attitudes toward credit/debt are identifiable by evaluating more deeply the meanings that they produce and how this impacts their consumption. Going forward, this knowledge may be used to train clergy to recognize patterns in themselves (and their congregants/parishioners). As $\mathrm{P} \& \mathrm{~B}$ note, sharing this information more widely "could help detect early warning signals" such that "treatments" may be prescribed, whether certain areas are in need of 
improvement, or simply to serve as confirmation that clergy are on the right path (2011, p.760). Incorporating similar evaluations into clergy financial literacy programs already underway may be most expedient.

Finally, these findings are undoubtedly limited to the extent of this small sample. However, evaluations of clergy meaning patterns akin to those conducted here may be used to extend this line of research. Consequently, the inclusion of female clergy as well as other denominations, or even faiths, in future studies would be welcome.

\section{ACKNOWLEDGEMENTS}

The author would like to express gratitude to Villanova University's Center for Church Management and the Center's fellowship advisors, Katie Day, Thomas Suermann de Nocker, and Scott Thumma for their comments, as well as to the Lilly Endowment for funding this project. Further, the author appreciates Lisa Peñaloza and Michelle Barnhart for being willing to share their materials. Many thanks also to Gloria Urrabazo for her invaluable assistance and graduate research assistants, Tricille Otineru and Sebastian Lühr.

\section{REFERENCES}

Association of Statisticians of American Religious Bodies (ASARB). (2010). Religious Congregations and Membership Study. Retrieved from http://www.thearda.com/rcms2010/

Barna Group. (2017). The State of Pastors: How Today's Faith Leaders are Navigating Life and Leadership in an Age of Complexity. Ventura: Barna Group.

Carnevale, A.P., Rose, S.J., \& Cheah, B. (2011). The College Payoff: Education, Occupations, Lifetime Earnings. Executive Summary. Washington, DC: Georgetown University Center on Education and the Workforce.

DeLambo, D. (2005). Lay Parish Ministers: A Study of Emerging Leadership. New York: National Pastoral Life Center.

Earls, A. (2020). Most Churches Cautiously Holding Services Again. Retrieved from https://ifewayresearch.com/2020/07/24/most-churches-cautiously-holding-service-again/

Evangelical Lutheran Church in America (ELCA). (2019). Resourceful Servants. Retrieved from https://www.resourcefulservants.org/about/

Evangelical Lutheran Church in America (ELCA). (2019). Summary of Congregational Statistics (as of 12/31/2017). Your Synod at a Glance. Retrieved from http://download.elca.org/ELCA\%20Resource\%20Repository/4E_Southwestern_Texas_data_kit.p df

Federal Reserve Bank of New York (FRB-NY). (2019, May). Quarterly Report on Household Debt and Credit 2019: Q1. Retrieved from https://www.newyorkfed.org/microeconomics/hhdc/background.html

Federal Reserve Board of Governors (FR-BOG) and NORC at the University of Chicago. (2016). Survey of Consumer Finances (SCF). Retrieved from https://www.federalreserve.gov/econres/scfindex.htm

Internal Revenue Service (IRS). (2019). Frequently Asked Questions: Ministers' Compensation and Housing Allowance. Retrieved from https://www.irs.gov/faqs/interest-dividends-other-types-ofincome/ministers-compensation-housing-allowance/ministers-compensation-housing-allowance

Internal Revenue Service (IRS). (2020a). Section 501(c)(3) Organizations - FUTA Exemption. Retrieved from https://www.irs.gov/charities-non-profits/charitable-organizations/section-501c3organizations-futa-exemption

Internal Revenue Service (IRS). (2020b). Economic Impact Payment Information Center. Retrieved from https://www.irs.gov/coronavirus/economic-impact-payment-information-center\#eligibility

Long, V.O., \& Heggen, C.H. (1988). Clergy Perceptions of Spiritual Health for Adults, Men, and Women. Counseling and Values, 3(32), 213-20. 
Pattison, M. (2020). PPP Loans to Parishes Not as Large, or as Many, as Some Believe. Retrieved from https://www.thecompassnews.org/2020/05/ppp-loans-to-parishes-not-as-large-or-as-many-assome-believe/

Peñaloza, L., \& Barnhart, M. (2011). Living U.S. Capitalism: The Normalization of Credit/Debt. Journal of Consumer Research, 4(38), 743-62.

Pew Research Center. (2014). Religious Landscape Study. Retrieved from http://www.pewforum.org/religious-landscape-study/

Rhee, S., Chang, J., \& Youn, R.S. (2003). Korean American Pastors' Perceptions and Attitudes Toward Child Abuse. Journal of Ethnic \& Cultural Diversity in Social Work, 1(12), $27-46$.

U.S. Department of Labor. (2020). U.S. Department of Labor Publishes Guidance on Pandemic Unemployment Assistance. Retrieved from https://www.dol.gov/newsroom/releases/eta/eta20200405

U.S. Department of the Treasury. (2020). The CARES Act Works for All Americans. Retrieved from https://home.treasury.gov/policy-issues/cares

U.S. Small Business Administration (SBA). (2020a). Paycheck Protection Program. Retrieved from https://www.sba.gov/funding-programs/loans/coronavirus-relief-options/paycheck-protectionprogram

U.S. Small Business Administration (SBA). (2020b). Economic Injury Disaster Loans. Retrieved from https://www.sba.gov/funding-programs/loans/coronavirus-relief-options/economic-injurydisaster-loans

Zech, C., \& Miller, R. (2007). The Professional Development Needs of Pastors and Parish Business Managers. Church, 23(2), 1-6.

\section{APPENDIX A}

Worth mentioning is that since this study was completed, the coronavirus (COVID-19) pandemic of 2020 has affected the world in ways entirely unforeseen, including the livelihood of clergy. Some houses of worship have had to close their doors to the public for some period of time, if not altogether, and attendance is restricted according to social distancing rules; possibly creating financial stress or adding to any that may already exist. However, the $\$ 2$ trillion U.S. Coronavirus Aid, Relief, and Economic Security Act - an economic relief package passed in March 2020 — does take into account clergy (U.S. Department of the Treasury, 2020)

Typically, church employees in the U.S. do not qualify for regular unemployment compensation, because they are exempt from paying unemployment taxes (IRS, 2020a). However, clergy may now be eligible for such benefits through December 2020, according to the Pandemic Unemployment Assistance program (U.S. Department of Labor, 2020).

In addition, the U.S. Small Business Administration (SBA) has extended financial assistance to faithbased organizations via two loan programs made available in 2020. The Paycheck Protection Program aims to help "businesses keep their workforce employed during the COVID-19 crisis" largely by covering payroll costs (SBA, 2020a). Whereas, the Economic Injury Disaster Loan Program "provides economic relief to small businesses and non-profit organizations that are currently experiencing a temporary loss of revenue" (SBA, 2020b).

Finally, clergy who are U.S. citizens (or resident aliens) may also be entitled to an Economic Impact Payment of $\$ 1,200$ (or $\$ 2,400$ if married), depending on their adjusted gross income (IRS, 2020b).

How have clergy responded to these offers of financial relief? During the spring and summer of 2020, several religious organizations, including Catholic parishes and Protestant congregations, submitted applications for and have received government assistance. As of 20 May 2020, roughly 15,000 Catholic parishes applied for PPP loans; 6,000 had received funds and 3,000 more "had their applications received," according to Patrick Markey, executive director of the Diocesan Fiscal Management Conference (Pattison, 2020). 
Based on an online survey of 443 pastors conducted by LifeWay Research in late July 2020, of the Protestant pastors who applied for assistance, "two in five (40 percent) say they applied for help through the CARES Act or the Small Business Administration, with 38 percent saying they applied and were approved. More than half (58 percent) say they have not applied" (Earls, 2020).

The full effect of the pandemic on clergy and their finances remains to be seen. The pandemic itself may be viewed as a life-changing event. Some aspects may be beyond their control. On the other hand, what approach will clergy take regarding financial matters and the use of credit/debt? The ability to interpret clergy attitudes toward credit/debt, as well as their tendencies and behaviors, as demonstrated in this study, could help to address these issues following the pandemic. 


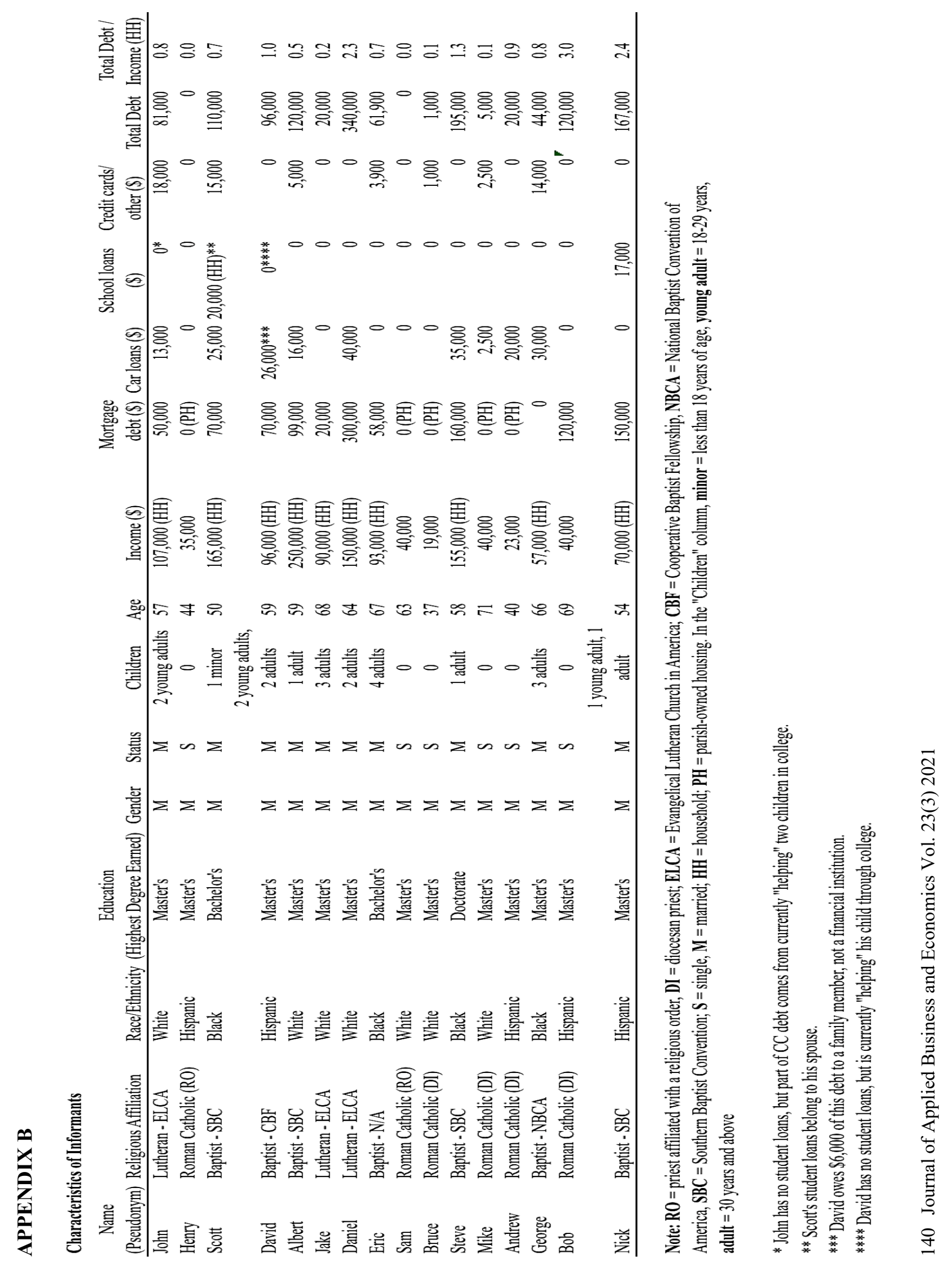

